\title{
REGULATING DERIVATIVES: A FUNDAMENTAL RETHINKING
}

\author{
STEVEN L. SCHWARCZ†
}

\begin{abstract}
The conventional wisdom is that derivatives are exotic and uniquely risky, although innovative, financial instruments. That perception has given rise to a regulatory patchwork described as "confusing, incomplete, [and] contradictory." This Article rethinks how derivatives should be regulated. It begins by demystifying derivatives. In contrast to the arcane industry-derived categories, the Article deconstructs derivatives more intuitively, by their economic functions, into two categories of traditional legal instruments-option contracts and guarantees. Being neither exotic nor uniquely risky, most derivatives should be regulated like those traditional instruments. The Article then explains why at least one subset of guarantees-financial guarantees with systemically important counterparties, which are epitomized by credit-default swap derivatives - can seriously threaten economic stability and why the absence of an insurable-interest requirement can further magnify that threat. Finally, the Article examines how to design regulation that efficiently targets that threat.
\end{abstract}

\section{TABLE OF CONTENTS}

Introduction 546

I. Deconstructing Derivatives

A. Functionally, Derivatives Are Option Contracts and Guarantees .551

1. Deconstructing Derivatives into Option Contracts.........552

2. Deconstructing Derivatives into Guarantees. 552

Copyright (C) 2020 Steven L. Schwarcz.

$\dagger$ Stanley A. Star Distinguished Professor of Law \& Business, Duke University School of Law; Senior Fellow, the Centre for International Governance Innovation (CIGI). I thank Dan Awrey, Colleen M. Baker, Anupam Chander, Gina-Gail Fletcher, Stephen J. Lubben, Timothy E. Lynch, Frank Partnoy, Pim Rank, Paolo Saguato, Michael Simkovic, Richard Squire, Gijs Van Setten, Yesha Yadav, and participants in the Duke Law School faculty "Ideas Lunch" for excellent comments and Ann (Zhouanan) Du, Emma Wheeler, Theodore L. Leonhardt, and Miata Eggerly for valuable research assistance.

1. See infra note 142 and accompanying text. 
B. Derivatives Are Not Inherently Riskier than Option

Contracts and Guarantees..................................................557

II. Analyzing Derivatives Risk

A. Financial Guarantees, and Thus CDS Contracts, Can Be Exceptionally Risky ..... 560

B. Having One or More Systemically Important Counterparties Can Magnify CDS Risk 564

C. The Absence of an Insurable-Interest Requirement Can Further Magnify CDS Risk.... 566

III. Derivatives Regulation is Often Flawed......................................568

A. Derivatives Regulation Often Presumes that Most Derivatives Are Uniquely Risky.... .568

B. Derivatives Regulation that Starts from that Flawed Premise Is Also Flawed... 571

IV. Designing Targeted Derivatives Regulation. 575

A. Building a Normative Framework for Financial Regulation. 575

B. Regulating Systemically Risky CDS Contracts that Guarantee Insurable Interests. 577

1. Limiting Credit Exposure 578

2. Correcting Cognitive Biases. 582

3. Setting Capital Requirements..........................................585

4. Reexamining the G20 Regulatory Scheme . 587

C. Regulating "Naked" Systemically Risky CDS

Contracts 589

1. Addressing Moral Hazard.... 589

2. Addressing the Multiplier Effect .......................................590

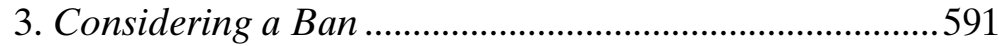

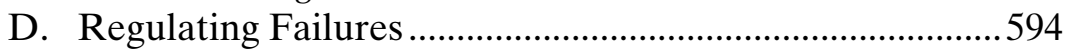

Conclusion. .597

Appendix: Model Regulatory Language Implementing this Article's Recommendations. 599

\section{INTRODUCTION}

The standard definition of a derivative is a financial contract about an underlying asset or assets from which the contract derives its value. ${ }^{2}$ This definition, which is followed by the International Swaps and

2. Lynn A. Stout, Derivatives and the Legal Origin of the 2008 Credit Crisis, 1 HARV. Bus. L. REV. 1, 6 (2011). 
Derivatives Association ("ISDA"), the leading industry trade organization, ${ }^{4}$ suggests that derivatives are exotic and complex, though possibly innovative, financial instruments..$^{5}$ An early history of highly publicized losses by large and sophisticated investors also suggests that derivatives are inherently riskier than other financial instruments. ${ }^{6}$ Reinforced by politicians and the media, these perceptions are widely shared, even by scholars. ${ }^{7}$

Especially since the 2007-2008 financial crisis ("financial crisis"), many observers believe that derivatives are also systemically risky, ${ }^{8}$ threatening economic stability by undermining the ability of the

3. See Glossary, INT'L SWAPS \& DERIVATIVES ASS'N, https://www.isda.org/1970/01/01/ glossary [https://perma.cc/YH6N-X4F9] (defining a derivative as a "financial instrument that ... derives its value from the price or rate of some other underlying assets such as bonds, loans, equities, currencies, commodities, indices, published rates or combinations of those assets").

4. See About ISDA, INT'L SwAPS \& DERIVATIVES ASS'N, https://www.isda.org/about-isda [https://perma.cc/3TKD-XF3F]. See generally Gina-Gail S. Fletcher, Engineered Credit Default Swaps: Innovative or Manipulative?, 94 N.Y.U. L. REV. 1073 (2019) (discussing ISDA).

5. See, e.g., Dan Awrey, Split Derivatives: Inside The World's Most Misunderstood Contract, 36 YALE J. ON REG. 495, 503-04 (2019) [hereinafter Awrey, Split Derivatives] (discussing derivatives' complexity); Dan Awrey, Complexity, Innovation, and the Regulation of Modern Financial Markets, 2 HARV. BUS. L. REV. 235, 245-58 (2012) (same); Timothy E. Lynch, Derivatives: A Twenty-First Century Understanding, 43 LOY. U. CHI. L.J. 1, 9 (2011) (referring to a common understanding of derivatives as "complex" and "exotic"); Steven McNamara, Financial Markets Uncertainty and the Rawlsian Argument for Central Counterparty Clearing of OTC Derivatives, 28 NotRE DAME J.L. ETHICS \& PUB. POL'Y 209, 218 (2014) (comparing derivatives with securities transactions).

6. In April 1994, Procter \& Gamble Co. announced a \$157 million trading loss speculating on interest rates through derivatives. Gabriella Stern \& Steven Lipin, Procter \& Gamble to Take a Charge To Close Out Two Interest-Rate Swaps, WALl St. J., Apr. 13, 1994, at A3. Several months later, Orange County, California, filed for bankruptcy protection due to a $\$ 2.5$ billion loss speculating on exotic financial instruments that included derivatives. Laura Jereski, Orange County Fund Losses Put at \$2.5 Billion, WALl ST. J., Dec. 12, 1994, at A3. These investors' sophistication did not extend to derivatives.

7. See Lynch, supra note 5, at 9 ("[R]egulatory, policy, and even legal discussions of derivatives are often muddled and demonstrate persistent misunderstandings of what derivatives are."); Stout, supra note 2, at 22-31 (arguing that the enactment in 2000 of the Commodities Futures Modernization Act set the stage for the 2007-2008 financial crisis by legalizing speculative nonexchange trading in derivatives, thereby dramatically increasing systemic risk); see also supra note 5 .

8. See, e.g., ERNST \& YOUNG, DODD-FRANK'S TITLE VII - OTC DERIVATIVES REFORM 1 (2013), https://www.eyjapan.jp/library/issue/us/gaap-weekly-update/pdf/GAAP-2012-10-25-0201.pdf [https://perma.cc/792T-24GB] ("Congress viewed the lack of regulation of OTC derivatives transactions as exacerbating the 2008 financial crisis ...."). OTC derivatives generally refer to over-the-counter, or privately negotiated, derivatives transactions. Id. at Introduction; see also infra text accompanying note 244 . 
financial system to function as a network. ${ }^{9}$ The media portrayed American International Group ("AIG") - which was potentially liable under multiple derivatives contracts to investors in mortgage-backed securities ("MBS") ${ }^{10}$ - as a poster child for that crisis. ${ }^{11}$ And even before the financial crisis, Warren Buffet famously referred to derivatives contracts as "financial weapons of mass destruction." 12

Derivatives regulation is largely premised on these perceptions, spawning laws that regulate most derivatives alike as if they are inherently riskier than other financial instruments (hereinafter, "uniquely risky"). ${ }^{13}$ That blunderbuss strategy can backfire, however. ${ }^{14}$ For example, although U.S. and foreign regulation requires most derivatives contracts to be cleared and settled through central

9. See Steven L. Schwarcz, Systemic Risk, 97 GEO. L.J. 193, 204, 207-08 (2008) [hereinafter Schwarcz, Systemic Risk] (defining systemic risk as risk that threatens the ability of the financial system to function as a network, thereby jeopardizing the real economy). References in this Article to "economic stability" and "financial stability" are intended to be synonymous, meaning the stability of the real economy.

10. See Christoph Henkel, Harmonizing European Union Bank Resolution: Central Clearing of OTC Derivative Contracts Maintaining the Status Quo of Safe Harbors, 22 TRANSNAT'L L. \& CONTEMP. PROBS. 81, 97 (2013) (explaining that AIG was "unable to post sufficient collateral to ensure meeting its [margin] obligations under the majority of its CDS agreements," leading to "a run on its collateral by its derivative counterparties and CDS protection buyers"); Stephen J. Lubben, Repeal the Safe Harbors, 18 AM. BANKR. INST. L. REV. 319, 320 (2010) (describing the AIG collapse as a "downward spiral"). MBS are promissory notes backed by interests in mortgage loans and thus not themselves derivatives. See FIRST EMPIRE Sec., Mortgage Backed Securities, http://www.1empire.com/Forms/MBS.pdf [https:// perma.cc/63SV-M8FR].

11. See, e.g., Michael S. Barr \& Joe Valenti, Commentary: How the CFPB Fight Is a Sign of the Next Financial Crisis, FORTUNE (Dec. 6, 2017, 4:16 PM), https://fortune.com/2017/12/06/cfpbdirector-mick-mulvaney-leandra-english [https://perma.cc/MD42-H59F].

12. Letter from Warren E. Buffet, Chairman of the Board, Berkshire Hathaway Inc., to the Shareholders, Berkshire Hathaway Inc. (Feb. 21, 2003), in BERKSHIRE HATHAWAY INC., 2002 ANNUAL REPORT 15 (2003), https://www.berkshirehathaway.com/2002ar/2002ar.pdf [https:// perma.cc/A5WK-D5FL]. The media has also suggested that Lehman Brothers' derivatives contracts were unusually systemically risky. See, e.g., Jeffrey McCracken, Lehman's Chaotic Bankruptcy Filing Destroyed Billions in Value, WALL ST. J. (Dec. 29, 2008, 12:01 AM), https:// www.ws].com/articles/SB123050916770038267 [https://perma.cc/9S6X-P2GB] (reporting that the early termination of Lehman Brothers' derivatives contracts is estimated to have cost the firm approximately $\$ 50$ billion).

13. See Stout, supra note 2, at 33 ("[T]he Congress that enacted Dodd-Frank clearly recognized that the OTC derivatives market had played a critical, if poorly understood, role in causing the [financial] crisis.").

14. See Lynch, supra note 5, at 11-12 (arguing that the standard definition of a derivative is "both over- and under-inclusive," thereby "hamper[ing] our ability to differentiate between socially useful and socially harmful derivatives" and "prolong[ing] the use of an outdated derivatives regulatory scheme"). 
counterparties, ${ }^{15}$ it is uncertain whether that requirement actually reduces, or inadvertently concentrates and increases, systemic risk. ${ }^{16}$ Furthermore, derivatives regulation does not always adequately address credit-default swap ("CDS") derivatives, which this Article shows to be the most systemically risky type of derivatives. ${ }^{17}$

This Article deconstructs derivatives into two categories of traditional legal instruments ${ }^{18}$ - option contracts and guaranteeswhich correspond to the derivatives' economic functions. ${ }^{19}$ Being neither exotic nor uniquely risky, most derivatives should be minimally regulated like those traditional instruments. ${ }^{20}$ However, at least one subset of guarantees-namely, guarantees of financial obligations ("financial guarantees") with large and highly interconnected financial institutions as counterparties ("systemically important counterparties" ${ }^{21}$ ) - can seriously threaten economic stability. CDS derivatives epitomize this subset. As a result, derivatives regulation should target the threat these specific derivatives pose.

15. See infra notes $127-33$ and accompanying text. Such clearing and settling is called central clearing; it usually occurs through a well-capitalized entity associated with a derivatives, commodities, or other securities exchange. Andrew Bloomenthal, Central Counterparty Clearing House (CCP), INVESTOPEDIA (Aug. 5, 2019), https://www.investopedia.com/terms/c/ccph.asp [https://perma.cc/MA3W-G7UY].

16. See infra notes $148-49$ and accompanying text.

17. See infra Parts IV.B \& IV.C (discussing credit-default swaps as the most systemically risky type of derivative).

18. This Article uses the term "instrument" in accordance with standard legal usage to mean any "legal document that defines rights, duties, entitlements, or liabilities." Instrument, BLACK's LAW DICTIONARY (11th ed. 2019).

19. See Robert C. Merton \& Zvi Bodie, A Conceptual Framework for Analyzing the Financial Environment, in THE Global Financial System: A FunCtional PersPeCtive 3-4 (Dwight B. Crane et al. eds., 1995) (viewing finance from a "functional perspective" by focusing on the underlying economic functions); Steven L. Schwarcz, Regulating Financial Change: $A$ Functional Approach, 100 MINN. L. REV. 1441, 1444 (2016) ("In thinking about regulating a dynamically changing financial system, it may be more effective... to focus on the system's underlying, and thus less time-dependent, economic functions than to tie regulation to any specific financial architecture.").

20. For example, neither loan agreements, option contracts, nor guarantees are generally regulated. The author is aware of only two types of restrictions on sophisticated parties entering into traditional legal instruments: restrictions on charging usurious rates of interest, see, e.g., Ann K. Wooster, Construction and Application of Usury Provisions in State Constitutions, 73 A.L.R. 6TH 571, 571 (2012) (listing and discussing usury laws in different states), and restrictions on margin lending as set forth in Federal Reserve Regulations G, 12 C.F.R. $\$ \$ 207.1-207.11$ (2020); T, §§ 220.1-220.132; U, §§ 221.1-221.125; and X, §§ 224.1-224.3.

21. This definition of systemically important counterparties should at least be deemed to encompass firms that are designated by the federal government as systemically important financial institutions ("SIFIs"). See infra note 218 and accompanying text. 
The Article proceeds as follows. Part I deconstructs derivatives into option contracts and guarantees. It also demonstrates that most derivatives are not inherently riskier than those traditional legal instruments. Part II analyzes what can make a derivative risky. It shows that, as financial guarantees, CDS contracts can threaten economic stability when they have one or more systemically important counterparties and that the absence of an insurable-interest requirement ${ }^{22}$ can further magnify that threat. Part III critiques existing derivatives regulation, arguing that such regulation often starts from the flawed premise that most derivatives are uniquely risky. Additionally, it shows that derivatives regulation that starts from that flawed premise-including aspects of the Group of Twenty ("G20") nations' regulatory scheme for derivatives, ${ }^{23}$ which is followed by the United States $^{24}$-is also flawed. Part IV argues that derivatives regulation should target CDS contracts that can threaten economic stability. It also analyzes how to design that regulation. The Appendix proposes model language for its implementation.

The Article's analysis focuses on derivatives counterparties that are sophisticated and understand their contracts. The extent to which regulators should impose "suitability" or similar requirements on less sophisticated or knowledgeable derivatives counterparties is beyond this Article's scope. ${ }^{25}$

22. This is a requirement that a person taking out insurance must derive some benefit from the continued existence of the insured person or property. See infra note 118 and accompanying text.

23. The G20 is "a collection of twenty of the world's largest economies [including the United States] formed in 1999" to "bring together the most important industrialized and developing economies to discuss international economic and financial stability." James McBride \& Andrew Chatzky, The Group of Twenty, COUNCIL ON FOREIGN RELS. (June 10, 2019), https:// www.cfr.org/backgrounder/group-twenty [https://perma.cc/3XSQ-ND2D].

24. See Richard Heckinger, Ivana Ruffini \& Kirstin Wells, Fed. Rsrv. Bank of Chi., Overthe-Counter (OTC) Derivatives, in UNDERSTANDING DERIVATIVES: MARKETS AND INFRASTRUCTURE ch. 3, at 32 (2014), https://www.chicagofed.org/ /media/publications/ understanding-derivatives/understanding-derivatives-chapter-3-over-the-counter-derivatives-pdf.pdf [https://perma.cc/MT7F-M92M]; Over-The-Counter Derivatives, FED. RSRV. BANK OF N.Y., https://www.newyorkfed.org/financial-services-and-infrastructure/financial-market-infrastructureand-reform/over-the-counter-derivatives [https://perma.cc/P86F-JJQ8] (observing that the United States is implementing the G20-proposed reforms "under the Dodd-Frank [Act] and rulemakings by U.S. agencies, including the Commodity Futures Trading Commission, Securities and Exchange Commission, as well as prudential regulators including the Federal Reserve").

25. For discussions of the suitability doctrine and its development under securities laws, see Willa E. Gibson, Investors, Look Before You Leap: The Suitability Doctrine Is Not Suitable for OTC Derivatives Dealers, 29 LOY. U. CHI. L.J. 527, 529 (1998); Lewis D. Lowenfels \& Alan R. Bromberg, Suitability in Securities Transactions, 54 BUS. LAW. 1557, 1558 (1999); Robert H. 


\section{DeConstructing Derivatives}

A proper understanding of derivatives will drive better derivatives regulation. Cutting through their mystique, derivatives are simply riskshifting contracts between two or more parties. ${ }^{26}$ That does not make them unique; indeed, the purpose of many financial contracts is to shift risks. ${ }^{27}$ Nor does the fact that derivatives derive their value from underlying assets ${ }^{28}$ make them unique; "[i]n reality, the value of every asset depends in part on something else." ${ }^{\prime 29}$ Moreover, derivatives may not even be innovative - the "Babylonians used [contracts similar to] derivative contracts to bet on the fates of desert trading caravans." ${ }^{30}$

Section A deconstructs derivatives by their economic functions into two categories of traditional legal instruments: option contracts and guarantees. Thereafter, Section B demonstrates that derivatives contracts are not inherently riskier than those traditional instruments.

\section{A. Functionally, Derivatives Are Option Contracts and Guarantees}

Market participants generally refer to four types of derivatives contracts: options, forwards, futures, and swaps. ${ }^{31}$ An option is a contract under which one party has the right to buy an asset from, or sell an asset to, another party on or before a future date at a specified

Mundheim, Professional Responsibilities of Broker-Dealers: Suitability Doctrine, 1965 DUKE L.J. 445,448

26. Derivative Financial Markets (Part I): Hearing Before the Subcomm. on Telecomm. \& Fin. of the H. Comm. on Energy \& Com., 103d Cong. 160 (1994) (statement of Alan Greenspan, Chairman, Board of Governors of the Federal Reserve System) ("The economic function of [derivatives] is to allow risks that formerly had been combined to be unbundled and transferred to those most willing to assume and manage each risk component."); Saul S. Cohen, The Challenge of Derivatives, 63 Fordham L. REV. 1993, 2005 \& n.61 (1995) ("[O]ne should understand that derivatives lessen volatility by efficiently shifting risk from parties less able or willing to bear it to others with the resources to more readily absorb such risk in exchange for a potential profit.").

27. See, e.g., Adam J. Levitin, Prioritization and Mutualization: Clearinghouses and the Redundancy of the Bankruptcy Safe Harbors, 10 BROOK. J. CORP. FIN. \& COM. L. 129, 141 (2015) (discussing why many financial contracts shift credit and market risk); Edward J. Janger \& John A.E. Pottow, Implementing Symmetric Treatment of Financial Contracts in Bankruptcy and Bank Resolution, 10 BROOK. J. CORP. FIN. \& COM. L. 155, 155 (2015) (discussing the various functions of financial contracts).

28. See supra note 2 and accompanying text.

29. Lynch, supra note 5 , at 28.

30. Stout, supra note 2, at 11 (citing LAURENT L. JACQUE, Global Derivatives DEBACLES: FrOM THEORY TO MALPRACTICE 4 (2010)).

31. See Lynch, supra note 5, at 20 (observing that, in "common parlance, derivatives are typically referred to as options, forwards, or swaps (or hybrids of each)" (citations omitted)). 
price. ${ }^{32} \mathrm{Next}$, a forward contract is "an agreement between two parties (a buyer and a seller) that calls for the delivery of an asset at a future point in time [at] a price agreed upon today." ${ }^{33}$ Similarly, a futures contract is a standardized "type of forward contract that is traded on an organized exchange and subject to exchange rules and clearing procedures." ${ }^{34}$ Finally, a swap is a contract under which "two parties agree to exchange (or 'swap') at least two identified sets of cash flows" on a future date. ${ }^{35}$

Although these industry-derived categories describe some of the mechanics of derivatives contracts, they do not provide an analytical foundation for regulating derivatives. To provide that foundation, this Article shows that all derivatives can be deconstructed by their economic functions into traditional option contracts and guarantees.

1. Deconstructing Derivatives into Option Contracts. One type of derivative, an option, maps directly onto the traditional category of legal instruments known as option contracts. ${ }^{36}$ Option contracts are contracts that "limit[] the promisor's power to revoke an offer." 37 They are therefore coextensive with option derivatives. For example, an option derivative under which one party has the right to buy an asset from another party on a future date, at a set price,,$^{38}$ is an option contract because the seller of that asset cannot revoke its promise to sell on those terms. ${ }^{39}$ Similarly, an option derivative under which one party has the right to sell an asset to another party on a future date, at a set price, is an option contract because the buyer of that asset cannot revoke its promise to buy on those terms. ${ }^{40}$

2. Deconstructing Derivatives into Guarantees. The International Monetary Fund ("IMF") and the finance literature refer to the three

32. Don M. Chance \& Robert BRooks, InTRoduction to DeRIVATIVES AND Risk MANAGEMENT 28 (9th ed. 2013).

33. Id. at 258 .

34. Lynch, supra note 5, at $20 \mathrm{n} .75$; see also CHANCE \& BROOKS, supra note 32, at 258.

35. Lynch, supra note 5, at $20 \mathrm{n} .76$. Swaps also could be viewed, economically, as a series of forward contracts. CHANCE \& BROOKS, supra note 32, at 413.

36. See, e.g., John D. CAlamari \& Joseph M. Perillo, Contracts 10 (4th ed. 1998) (describing option contracts as a traditional contract category).

37. ReSTATEMENT (SECOND) OF CONTRACTS § 25 (AM. L. INST. 1981) (defining an option contract).

38. See supra note 32 and accompanying text (defining an option derivative).

39. See RESTATEMENT (SECOND) OF CONTRACTS $§ 87$ (AM. L. INST. 1981).

40. See id. 
remaining types of derivatives - forward contracts, futures contracts, and swaps ${ }^{41}$-as "forward-type contracts." ${ }^{42}$ Forward-type contracts represent arrangements in which the parties agree to exchange-that is, to swap-identified assets (or their market value ${ }^{43}$ ) or cash flows at a future time. Thus, in a forward contract, the parties agree to deliver an asset at a future time in exchange for an agreed price, ${ }^{44}$ in a futures contract, the parties agree on standardized terms to deliver an asset at a future time in exchange for an agreed price ${ }^{45}$ and in a swap, the parties agree to exchange identified cash flows at a future time. ${ }^{46}$

Although the term "forward-type contract" streamlines derivatives-industry terminology, it does not describe a category of traditional legal instruments. Functionally, however, all forward-type contracts fit into the traditional category of "guarantees," which are promises or assurances that certain conditions will be fulfilled. ${ }^{47}$ To understand why, consider the most widely used forward-type contracts:

41. See supra note 31 and accompanying text.

42. Int'L Monetary Fund, Monetary and Financial Statistics Manual and COMPILATION GUIDE para. 4.160 (2017) [hereinafter IMF MANUAL], https://www.imf.org/ / media/Files/Data/Guides/mfsmcg_merged-web-pdf [https://perma.cc/7WXU-LJT9] ("There are two broad types of financial derivatives - options and forward-type contracts."); id. para. at 4.162 ("A forward-type contract ... is an unconditional contract by which two counterparties agree to exchange a specified quantity of an underlying item (financial or real) at an agreed-upon contract price (the strike price) on a specified date."). Although the IMF Manual uses the term "financial derivatives," there does not appear to be any material difference between that term and this Article's term "derivatives." Cf. E-mail from Colleen M. Baker, Assistant Professor of Legal Stud., Price Coll. of Bus., Univ. of Oklahoma, to author (Dec. 23, 2019) (on file with author) ("Finance literature breaks derivatives into options and forwards.").

43. See infra notes $48-50$ and accompanying text.

44. See supra note 33 and accompanying text.

45. See supra note 34 and accompanying text (observing that futures contracts are simply standardized types of forwards).

46. See supra note 35 and accompanying text.

47. See Guarantee, LEXICO, https://www.lexico.com/en/definition/guarantee [https://perma.cc/ QP7N-W6WN] (defining a "guarantee" as a "formal promise or assurance (typically in writing) that certain conditions will be fulfilled"). This Article uses the spelling "guarantee" rather than the much less common "guaranty" spelling. Whereas the latter spelling sometimes refers only to a financial guaranty, the former spelling includes, in the author's experience, all guarantees. But cf. E-mail from Pim (W.A.K.) Rank, Professor of Fin. L., Leiden Univ. Faculty of L., to author (Feb. 10, 2020) (on file with author) (clarifying that whereas this Article uses the word guarantee "to refer both to the situation where a party simply commits itself to fulfill a particular obligation and to the situation where a party undertakes to answer for the performance of another person's debt or obligation in the event of a default by the person primarily responsible," of which a CDS is "a typical example," lawyers in "the Netherlands and many other continental European jurisdiction[s] . . would not use the word guarantee to refer to the first situation"). 
commodity swaps, interest-rate swaps, and CDS contracts. ${ }^{48}$ In a typical commodity swap, Parties A and B effectively bet on the market value of an identified unit of commodity $\mathrm{Y}$ at time1 ("t1") in the future. If the market value of that unit at $\mathrm{t} 1$ exceeds $\$ \mathrm{X}$, say by $\$ \Delta$, the contract requires Party A to pay $\$ \Delta$ to Party B. If the market value of that unit at t1 is below $\$ \mathrm{X}$, say by $\$ \Phi$, the contract requires Party B to pay $\$ \Phi$ to Party A.$^{49}$ The swap functions economically, then, as two guarantees. Each party to the transaction guarantees the other party that the market value of a unit of commodity Y will not be above or below $\$ \mathrm{X}$ at $\mathrm{t} 1$, respectively. Unless the value of the unit is $\$ \mathrm{X}$ at $\mathrm{t} 1$, one party pays the other $\$ \Delta$ or $\$ \Phi$, according to which guarantee was not met. Although parties historically settled these types of derivatives contracts by actual delivery of commodities, cash settlements are now more common because they are convenient. ${ }^{50}$

Similarly, in a typical interest-rate swap, Parties A and B agree to exchange a stream of floating interest-rate payments for a stream of fixed interest-rate payments, based on an identified principal amount, identified interest rates, and a specified time period. ${ }^{51}$ The party that initiates the swap-say Party A-usually is trying to manage the exposure created by its obligations to pay a floating interest rate on an underlying loan. Party A accomplishes this in a swap by paying a

48. See, e.g., Carney Simpson, Note, Do End-Users Get the Best of Both Worlds? - Title VII of Dodd-Frank and the End-User Exception, 69 WASH. \& LEE L. REV. 1759, 1775 (2012) (reporting on a 2010 ISDA survey showing that " $80 \%$ [of derivatives counterparties] use the OTC market for interest rate swaps, 59\% for currency swaps, $27 \%$ for credit default swaps, $25 \%$ for equity swaps, and $32 \%$ for energy/commodity swaps"). Recall that CDS is the acronym for a credit-default swap. Justin Kuepper, Credit Default Swap (CDS) Definition, INVESTOPEDIA (Mar. 20, 2020), https://www.investopedia.com/terms/c/creditdefaultswap.asp [https://perma.cc/ZYK8HFFX].

49. For example, assume Parties A and B make their contract in April 2019, that the identified unit of commodity $\mathrm{Y}$ is one ton of iron ore, that $\mathrm{t} 1$ is April 15, 2020, and that $\$ \mathrm{X}$ is $\$ 90$. In April 2019, the market value of a ton of iron ore was approximately $\$ 93.70$. See Iron Ore Prices from May 2019 to May 2020 (in U.S. Dollars per Dry Metric Ton Unit), STATISTA, https:// www.statista.com/statistics/300419/monthly-iron-ore-prices [https://perma.cc/YQ92-RAJS]. In mid-April 2020, the market value of a ton of iron ore had fallen to approximately $\$ 84.73$, see id., which is below $\$ 90$ by $\$ 5.27$ (that is, $\$ \Phi=\$ 5.27$ ). Under the contract, Party B must pay $\$ 5.27$ to Party A.

50. See James Chen, Cash Settlement, InVEstopediA (Apr. 4, 2019), https:// www.investopedia.com/terms/c/cashsettlement.asp [https://perma.cc/2FL5-WUPZ]; $c f$. MICHAEL DURBin, All ABOUt DeRIVATIVEs 1 (2d ed. 2010) (observing that although "some derivatives guarantee something other than a price [like performance of an obligation or even] things like temperature or rainfall," the "vast majority of derivatives are price guarantees").

51. See, e.g., Justin Kuepper, Interest Rate Swap Definition, INVESTOPEDIA (Feb. 19, 2019), https://www.investopedia.com/terms/i/interestrateswap.asp [https://perma.cc/8CF6-L53E]. 
stream of fixed interest-rate payments to its counterparty, Party B, and receiving in exchange the stream of floating interest-rate paymentswhich it then uses to pay its lender. ${ }^{52}$ If the amount of the stream of fixed interest-rate payments exceeds the amount of the stream of floating interest-rate payments, say by $\$ \Delta$, Party A would be required to pay $\$ \Delta$ to Party B. ${ }^{53}$ If the amount of the stream of floating interestrate payments exceeds the amount of the stream of fixed interest-rate payments, say by $\$ \Phi$, Party B would be required to pay $\$ \Phi$ to Party A. Party B would agree to the swap if it believes the stream of fixed interest-rate payments it receives from Party A will exceed the stream of floating interest-rate payments that it pays to Party A. ${ }^{54}$

Economically, an interest-rate swap-just like a commodity swap-functions as two guarantees. Party A guarantees Party B that the amount of the stream of fixed interest-rate payments exceeds the amount of the stream of floating interest-rate payments. Party B guarantees Party A that the amount of the stream of floating interestrate payments exceeds the amount of the stream of fixed interest-rate payments. ${ }^{55}$

The last most commonly used forward-type contract, a CDS contract, is most transparently a guarantee. Indeed, it is a special type called a "financial guarantee." 56 In a typical CDS contract, ${ }^{57}$ a protection or credit "seller" (say Party A) agrees to assume, in exchange for a fee, a protection or credit "buyer's" (say Party B's) credit risk with respect to certain debt obligations owed by a specified borrower or other obligor. ${ }^{58}$ If a "credit event" - for example, default or bankruptcy-occurs in respect of that obligor, Party A will either pay Party B an amount calculated by reference to the post-default

52. See Interest Rate Swaps, PIMCO, https://global.pimco.com/en-gbl/resources/education/ understanding-interest-rate-swaps [https://perma.cc/34UJ-3Y66] (explaining interest-rate swaps generally).

53. The actual settlement times for payment depend on the specific contract.

54. Interest Rate Swaps, supra note 52.

55. If the amount of the stream of fixed interest-rate payments exceeds the amount of the stream of floating interest-rate payments, say by $\$ \Delta$, Party A would be required to pay $\$ \Delta$ to Party $B$. If the amount of the stream of floating interest-rate payments exceeds the amount of the stream of fixed interest-rate payments, say by $\$ \Phi$, Party B would be required to pay $\$ \Phi$ to Party A.

56. See infra note 62 and accompanying text.

57. CDS contracts are sometimes referred to as credit derivatives. IMF MANUAL, supra note 42, at para. 4.180. References in this Article to CDS contracts and credit derivatives are synonymous.

58. Steven L. Schwarcz, Structured Finance: A Guide to the Principles of Asset SECURITIZATION $§ 10: 1.1$ (Adam D. Ford ed., 3d ed. 2010). 
value of the debt obligations or buy the debt obligations for their full face value from Party B. ${ }^{59}$

Although market participants regard CDS contracts as swaps ${ }^{60}$ and the "S" in the CDS acronym stands for "swap," a CDS is not a typical swap. ${ }^{61}$ Rather, it epitomizes a financial guarantee-a contractual arrangement in which one party, in exchange for a fee, agrees for the benefit of another party to assume credit risk on a debt obligation. ${ }^{62}$ In the author's experience, market participants sometimes characterize a CDS as "a guarantee documented as a derivative" by writing the contract on an ISDA form.

59. Id. $\S 10: 3.1$. For example, assume Party B makes a loan to Party C, and Party B is concerned about Party C's ability to repay the loan. Party B, as protection buyer, may then enter into a CDS contract with Party A, as protection seller, under which Party A agrees to make any payments that Party $\mathrm{C}$ fails to make. In exchange for this protection, Party B pays Party A a fee. See, e.g., Credit Default Swaps, PIMCO, https://www.pimco.com/en-us/resources/education/ understanding-credit-default-swaps [https://perma.cc/934H-ZLRZ] (explaining credit-default swaps). Protection sellers may enter into many CDS contracts, thereby earning fee income while helping market participants to hedge risk.

60. Congress, for example, included in its definition of a "'swap agreement' ... any such agreement, contract, or transaction commonly known as an interest rate swap, including a . . . debt swap, credit spread, credit default swap, [or] credit swap." Commodity Futures Modernization Act of 2000, Pub. L. No. 106-554, app. E, tit. III, sec. 301(a), § 206A(a), 114 Stat. 2763A-365, 2763A-449 to -450 .

61. Documenting a CDS as a derivatives contract on an ISDA form does not make it a traditional swap. In a traditional swap, the counterparties exchange cash flows on underlying financial instruments. The business goal is to trade, or swap, the variable cash-flow risks between the counterparties. See Policy Statement Concerning Swap Transactions, 54 Fed. Reg. 30,694, 30,695 (July 21, 1989) ("[A] swap may be characterized as an agreement between two parties to exchange a series of cash flows measured by different interest rates, exchange rates, or prices with payments calculated by reference to a principal base....”). In a CDS, the guarantee fee is not variable but a fixed-payment obligation. See Stout, supra note 2, at 6 (describing CDS transactions). But cf. Darrell Duffie, Credit Swap Valuation, 1999 FIN. ANALYSTS J. 73, 73 (arguing that the "term 'swap' applies to credit swaps because they can be viewed, under certain ideal conditions ..., as a swap of a default-free floating-rate note for a defaultable floating-rate note"). For an introduction to ISDA's form documentation, see generally ISDA, LEGAL GUIDELINES FOR SMART DERIVATIVES CONTRACTS: THE ISDA MASTER AGREEMENT (Feb. 2019), https://www.isda.org/a/23iME/Legal-Guidelines-for-Smart-Derivatives-Contracts-ISDAMaster-Agreement.pdf [https://perma.cc/RN4V-CSVL].

62. See Guarantee, supra note 47 (providing a legal definition of "guarantee" as a "formal pledge to pay another person's debt or to perform another person's obligation in the case of default"). U.K. law, for example, recognizes a CDS's essential guarantee function. See, e.g., Leonard Ng, Credit Default Swaps, Guarantees and Insurance Policies: Same Effect, Different Treatment?, 25 BUTTERWORTHS J. INT'L BANKING \& FIN. L. 664, 664-66 (2010) (observing that U.K. financial and insurance law treats CDS contracts and guarantees similarly in many important respects, in sharp contrast to how that law treats "insurance contracts," with which they are sometimes confused). 
By their economic functions, derivatives contracts are thus option contracts and guarantees. ${ }^{63}$ This suggests that derivatives contracts, inherently, are no riskier than those traditional legal instruments. ${ }^{64}$ Section B demonstrates this proposition.

\section{B. Derivatives Are Not Inherently Riskier than Option Contracts and Guarantees}

The widely held perception that derivatives are inherently riskier than other financial instruments is based on anecdotal information ${ }^{65}$ and has never been rigorously tested. This Section examines and corrects this misperception, showing that derivatives are not inherently riskier than option contracts and guarantees. ${ }^{66}$

Some argue that derivatives are inherently riskier because they are bets. ${ }^{67}$ However, virtually all financial instruments are bets. An option contract is a bet on the future price of an asset. ${ }^{68} \mathrm{~A}$ guarantee is a bet by the guarantor that the guaranteed obligation will not default. Even a loan agreement is a bet by a lender that the borrower will repay the loan with interest on a timely basis. ${ }^{69}$

63. E-mail from Timothy E. Lynch, Associate Professor of L., UMKC Sch. of L., to author (Jan. 2, 2020) (agreeing "that all derivatives can be reduced to options and what [I] call guarantees"); see also Norman Menachem Feder, Deconstructing Over-the-Counter Derivatives, 2002 COLUM. BUS. L. REV. 677, 691 (discussing the "limited number of basic building blocks that constitute most OTC derivatives products"); Alireza M. Gharagozlou, Unregulable: Why Derivatives May Never Be Regulated, 4 BRoOK. J. CorP. FIN. \& COM. L. 269, 293-94 (2010) ("Derivatives are contracts entered into by willing and informed parties, for the age-old purpose of risk allocation. Parties have entered into such arrangements in one form or another for millennia.").

64. Professor Lynch suggests that "even guarantees can be reconstructed as options and vice versa." E-mail from Timothy E. Lynch, supra note 63. Even if some (or all) of what this Article calls guarantees can be reconstructed that way, all derivatives would still fall within this Article's categories of option contracts and guarantees - namely, traditional financial instruments.

65. Cf. supra notes 8-12 and accompanying text (discussing Warren Buffet's description of derivatives as financial weapons of mass destruction and the media's portrayal of AIG's derivatives problems as a poster child for the financial crisis).

66. This discussion in Section B is adapted from Steven L. Schwarcz, Central Clearing of Financial Contracts: Theory and Regulatory Implications, 167 U. PA. L. REV. 1327, 1336-39 (2019) [hereinafter Schwarcz, Central Clearing of Financial Contracts].

67. See, e.g., Stout, supra note 2, at 6 (characterizing derivatives contracts as bets, given that they are "agreements between parties that one will pay the other a sum of money that is determined by whether or not a particular event occurs in the future").

68. See supra note 32 and accompanying text (observing that an option contract gives one party the right to buy an asset from, or to sell an asset to, another party at a specified price in the future).

69. See Schwarcz, Central Clearing of Financial Contracts, supra note 66, at 1336. 
Others argue that derivatives are inherently riskier than other financial instruments because they are much more volatile given that "[u]nlike other contracts, the value of [derivatives contracts] typically can change rapidly based on the fluctuating value of the underlying assets or collateral, prevailing market conditions and other factors." ${ }^{\circ 0}$ That volatility, the argument goes, can create the possibility of indeterminate liability. Consider, for example, an interest-rate swap in which Party A exchanges its fixed interest-rate payments for Party B's floating-rate payments. If interest rates fall, the argument goes, Party A will take a loss that cannot be precisely quantified ex ante because it will depend on the magnitude of the interest-rate change.

That argument fails to recognize, however, that derivatives counterparties usually can estimate the limits of their potential liability. ${ }^{71}$ In the foregoing example, there is indeterminate liability insofar as the parties cannot know the sign, positive or negative, and magnitude of the interest-rate change at the time they enter into the derivatives contract. In reality, however, they will know from market experience and data modeling the likely maximum range of any interest-rate change within the timeframe of their contractual settlement date. ${ }^{72}$ Thus, if Party A contracts to sell one thousand shares of XYZ stock to Party B a year hence at seventy dollars per share, its current market value, then there is indeterminate liability insofar as the parties cannot currently know how the sign and magnitude of XYZ stock's market value will change. In reality, counterparties minimize this indeterminacy by again relying on market experience and their ability to calculate the likely maximum range of XYZ stock's change within the next year. ${ }^{73}$

70. Exploring Chapter 11 Reform: Corporate and Financial Institution Insolvencies; Treatment of Derivatives: Hearing Before the Subcomm. on Regul. Reform, Com. \& Antitrust L. of the H. Comm. on the Judiciary, 113th Cong. 40 (2014) (statement of Seth Grosshandler, Partner, Cleary Gottlieb Steen \& Hamilton LLP).

71. See, e.g., René M. Stulz, Should We Fear Derivatives?, 18 J. ECON. PERSP. 173, 186 (2004) (observing that, "[s]ince 1994, regular users of derivatives have made considerable progress in measuring the risks of derivatives portfolios [and w]ith these tools, firms that use derivatives regularly know their risks reasonably well," but cautioning that "these measurement tools do not always work well").

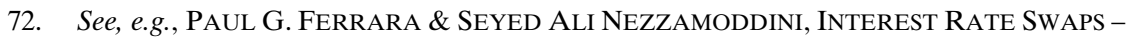
AN EXPOSURE ANALYSIS 26 (2013), https://www.soa.org/globalassets/assets/files/research/ projects/research-2013-interest-rate-swaps.pdf [https://perma.cc/7D7Z-KGUQ] (discussing how parties estimate their likely exposure to interest-rate change within the timeframe of their contractual settlement date).

73. See, e.g., infra note 76 and accompanying text (observing that accountants have devised a range of methodologies to estimate potential liability for even the most complex derivatives). 
Although the foregoing examples are relatively simple, counterparties usually can estimate the limits of their potential liability even for much more complex derivatives. In the United States, the disclosure of this liability is an accounting requirement; derivatives are to be measured at fair value and reported as either assets or liabilities. ${ }^{74}$ The goal is to ensure parties provide the "credible, transparent, and comparable financial information" that undergirds "the efficient functioning of the economy." 75 To facilitate this required disclosure, accountants have devised a range of methodologies to estimate potential liability for even the most complex derivatives. ${ }^{76}$

In short, derivatives are not inherently riskier than the option contracts and guarantees they functionally represent. ${ }^{77}$

74. 3 ACCT. STANDARDS CODIFICATION $\$$ 815-10-10 (FIN. ACCT. STANDARDS BD. 2020). The standards set by the Financial Accounting Standards Board are recognized by the SEC as " "generally accepted' for purposes of the federal securities laws." Commission Statement of Policy Reaffirming the Status of the FASB as a Designated Private-Sector Standard Setter, Securities Act Release No. 8221, Exchange Act Release No. 47,743, Investment Company Act Release No. 26,028, 68 Fed. Reg. 23,333 (May 1, 2003).

75. FIN. ACCT. STANDARDS BD., FACTS ABOUT FASB 1 (2007), https://www.fasb.org/cs/ BlobServer?blobcol=urldata\&blobtable $=$ MungoBlobs\&blobkey $=$ id\&blobwhere $=1175818791156$ \&blobheader=application \%2Fpdf [https://perma.cc/ZS7T-U3HQ].

76. See, e.g., ERnst \& Young, CREdit VAluATION AdJUSTMENTS FOR Derivative CONTRACTS 1, 5-6 (2014), https://www.ey.com/Publication/vwLUAssets/EY-credit-valuationadjustments-for-derivative-contracts/\$FILE/EY-Applying-FV-April-2014.pdf [https://perma.cc/ S8CK-LQSH]. This publication discusses various approaches for calculating valuation adjustments to value derivatives contracts "at fair value." Id. Fair value, in this context, is defined by International Financial Reporting Standards ("IFRS") 13 as "the price that would be ... paid to transfer a liability in an orderly transaction between market participants at the measurement date," INT'L FIN. REPORTING STANDARDS FOUND., IFRS 13: Fair Value Measurement, in IFRS STANDARDS, at A669, A673 (2020), http://eifrs.ifrs.org/eifrs/bnstandards/en/IFRS13.pdf [https:// perma.cc/LRS4-WF7E]. The Deloitte accounting firm defines fair value under IFRS 13 more intuitively as "how much the reporting entity has to pay to a market participant such that the market participant is willing to take over the liability." DELOITTE LLP, CLEARLY IFRS: SUMMARY GUIDANCE AND PRACTICAL TIPS FOR IFRS 13 - FAIR VALUE MEASUREMENT 1 (2014), https://www.deloitte.com/content/dam/Deloitte/ca/Documents/audit/ca-en-audit-clearlyifrs-fair-value-measurement-ifrs-13.pdf [https://perma.cc/NJC9-XUAK]. The "most advanced approach" is the Expected Future Exposure ("EFE") approach, which is used by banks and other financial institutions with large derivative portfolios and can be "used for many types of derivatives." ERnst \& YOUNG, CREDIT VALUATION ADJUSTMENTS FOR DERIVATIVE CONTRACTS, supra, at 5-6. Because the EFE approach "can be very complex and . . . needs to be executed by quantitative experts and requires access to significant IT systems," many firms "have adopted alternative approaches for estimating" liability on their derivatives contracts. Id.

77. See Feder, supra note 63, at 721 ("[M] any of the risks that are common to most OTC derivatives are common to other financial instruments as well."). 


\section{ANALYZING DERIVATIVES RISK}

Although derivatives are not inherently riskier than option contracts and guarantees, there is little doubt that derivatives sometimes create very significant risk. This Part first argues that CDS contracts, which constitute financial guarantees, can be exceptionally risky. Thereafter, it argues that CDS contracts that have one or more systemically important counterparties can become systemically risky and that the absence of an insurable-interest requirement can further magnify that risk.

\section{A. Financial Guarantees, and Thus CDS Contracts, Can Be Exceptionally Risky}

For at least four reasons, financial guarantees are riskier than other types of guarantees: they ensure against unpredictable future events, in contrast with non-financial guarantees; they are subject to more economy-wide risks; they overrely on quantitative modeling and thus are more subject to bias ${ }^{78}$ and they guarantee instruments that can become correlated.

First, financial guarantees ensure against unpredictable future events. All guarantees are risky, of course, because they ensure future events. Non-financial guarantees, though, normally ensure reasonably predictable events. Consider typical property-and-casualty and life insurance, for instance, which comprises the great bulk of non-financial guarantees. Traditionally, insurance companies will not insure events absent rigorous statistical and actuarial data. ${ }^{79}$ Financial obligations, in contrast, tend to be sui generis and harder to predict. For example, decades of residential mortgage-loan data did not predict the unprecedented 2007-2009 housing-price decline, which was greater than during the Great Depression. Even the rating agencies failed to

78. For a discussion of the impact of biases, see generally Steven L. Schwarcz, Regulating Financial Guarantors: Abstraction Bias as a Cause of Excessive Risk-Taking, 11 HARV. BUS. L. REV. (forthcoming 2021) [hereinafter Schwarcz, Regulating Financial Guarantors], https:// ssrn.com/abstract=3431345 [https://perma.cc/K5ZG-L3BD].

79. See, e.g., Charles Nyce, Am. Inst. For Chartered Prop. CAS. Underwriters/ Ins. Inst. Am., Predictive AnAlytics White PAPER 2 (2007), http://www.the-digitalinsurer.com/wp-content/uploads/2013/12/78-Predictive-Modeling-White-Paper.pdf [https://perma.cc/ KS2T-3ELB] (demonstrating insurance companies' use of predictive analytics and explaining that proprietary data, as well as data from "numerous third party sources," allow insurance companies to develop predictive models by which to determine premiums). 
predict that decline. ${ }^{80}$ Moreover, there are "no standardized agreements or controls that exist" for over-the-counter debt securities. ${ }^{81}$

Second, financial guarantees are also subject to greater uncertainty than other guarantees because they are more exposed to "systematic," 82 economy-wide risks. Non-financial guarantees are less susceptible to economy-wide risks because a guarantor can better diversify its coverage. In property-and-casualty life insurance, for example, insurers normally can diversify their risks sufficiently to accurately estimate their future losses, enabling them to price their insurance accordingly. ${ }^{83}$ A financial guarantor, however, cannot easily diversify its coverage because most, if not all, financial obligations are affected systematically - that is, in the same orderly way - by economywide risks such as interest rate changes, inflation, recessions, and war. ${ }^{84}$

Third, in light of the foregoing uncertainties, financial guarantors are prone to overrely on quantitative models, which provide a (sometimes unjustified) sense of comfort..$^{85}$ These models, in turn, can

80. See, e.g., Corelogic, Evaluating the Housing Market Since the Great RECESSION 4 (2018) (noting S\&P's precrisis model that housing prices could fall as much as 20 percent, whereas they actually fell around 33 percent-more than their fall in the Great Depression); $c f$. Adam J. Levitin \& Susan M. Wachter, Explaining the Housing Bubble, 100 GEO. L. J., 1177, 1234 (2012) (discussing the failure of rating agencies to provide reliable ratings on MBS because of the securities' lack of "multicycle experience" and the variety of "collateral, borrower strength, and credit enhancements" across deals, none of which are alike).

81. Protiviti KnowledgeLeader, What is Financial Instrument Risk?, KNOWLEDGELEADER (Jan. 25, 2018, 5:13 PM), https://info.knowledgeleader.com/financial-instrument-risk [https:// perma.cc/G3S6-4CPV].

82. Systematic risk means "risk that cannot be diversified away and therefore affects most, if not all, market participants." Schwarcz, Systemic Risk, supra note 9, at 204. Systematic risk is different than systemic risk, which refers to risk that could undermine the ability of the financial system to function as a network. Id.

83. See, e.g., Viral V. Acharya, John Biggs, Hanh Le, Matthew Richardson \& Stephen Ryan, Systemic Risk and the Regulation of Insurance Companies, in REGULATING WALL STREET: THE DodD-Frank ACT AND THE NeW ARCHITECT OF Global FinAnCE 241 (Viral V. Acharya, Thomas F. Cooley, Matthew Richardson \& Ingo Walter eds., 2011) ("In competitive markets, insurers price diversifiable risks on an actuarial basis, yielding tremendous utility gains to the previously exposed individuals and businesses.").

84. See id. at 253 (noting that nontraditional insurance activities are more exposed to macroeconomic variables); Matthew C. Turk, The Convergence of Insurance with Banking and Securities Industries, and the Limits of Regulatory Arbitrage in Finance, 2015 COLUM. BUS. L. REV. 967, 989-99 (discussing the convergence of traditional insurance and finance).

85. See, e.g., Raphaële Chappe, Edward Nell \& Willi Semmler, The Financial Crisis of 2008 as Cognitive Failure: An Overview of Risk over Uncertainty, 57 BERKELEY J. SOCIO. 9, 23 (2013) (discussing problems with the mathematical models that were used precrisis for MBS risk management and arguing that by unreliably predicting the magnitude and frequency of rare events, they allowed investors to "get lulled with a false sense of security"). 
foster cognitive biases-implicit simplifications of how one perceives reality. ${ }^{86}$ For example, optimism bias can cause financial guarantors to believe they can quantify unquantifiable risks ${ }^{87}$ While parties to any financial contract may be subject to optimism bias ${ }^{88}$ financial guarantors are also subject to another important cognitive bias. Because they do not actually transfer their property at the time they make a guarantee, financial guarantors may view their risk-taking more abstractly than, say, a lender that advances its own funds to a borrower. ${ }^{89}$ This "abstraction bias" causes financial guarantors to underestimate the risk, ${ }^{90}$ even after discounting for the fact that payment on a guarantee is a contingent obligation. ${ }^{91}$ Empirical findings confirm that abstraction bias is real and that it can influence even sophisticated financial guarantors. ${ }^{92}$

Fourth, the instruments underlying financial guarantees can become correlated. And as they become correlated, so do the risks on the guarantees. This occurred, for example, when home-mortgage-loan obligations became correlated during the financial crisis. ${ }^{93}$ Lenders believed that repayment of those obligations was diversified by the variation in regional housing prices, not recognizing that nationally all housing prices were overvalued. In 2007, housing prices throughout the

86. Steven L. Schwarcz, Regulating Complacency: Human Limitations and Legal Efficacy, 93 Notre DAME L. REV. 1073, 1079 (2018).

87. See Jon D. Hanson \& Douglas A. Kysar, Taking Behavioralism Seriously: The Problem of Market Manipulation, 74 N.Y.U. L. REV. 630, 661 (1999) ("When the pertinent events are not easily predictable and the feedback is not unambiguous, experts tend to be even more overconfident than laypersons.").

88. Iman Anabtawi \& Steven L. Schwarcz, Regulating Systemic Risk: Towards an Analytical Framework, 86 Notre DAME L. REV. 1349, 1366 (2011) [hereinafter Anabtawi \& Schwarcz, Regulating Systemic Risk].

89. Schwarcz, Regulating Financial Guarantors, supra note 78 (manuscript at 5).

90. Id.

91. Posit, for example, that a firm is deciding between two options: to lend $\$ 1$ million to a borrower for a year with 3 percent interest and a 0.5 percent chance of the borrower defaulting on payment; or to guarantee a one-year $\$ 1$ million loan made by another lender to the same borrower (and thus with the same 0.5 percent chance of default), for a guarantee fee having the same economic value. Although the expected value of these options to the firm would be equivalent, abstraction bias would cause the firm to view the guarantee option less seriously. Id. (manuscript at $5 \mathrm{n} .23$ ).

92. See generally id. (comparing the pricing of otherwise parallel risk-taking by financial firms that invest capital at the outset of securitization transactions and by financial guarantors of those transactions, and finding that the initial investors demand substantially higher pricing than the financial guarantors for taking the same amount of risk).

93. See, e.g., InT'L MONETARy Fund, Global FinAnCIAL StABility RePORT 5-20 (2008), https://www.imf.org/ /media/Websites/IMF/imported-full-text-pdf/external/pubs/ft/gfsr/ 2008/02/pdf/_text.ashx [https://perma.cc/8UPX-66LH]. 
country dropped precipitously, and borrowers generally began defaulting on their mortgage loans.$^{94}$ It often is difficult to foresee these correlations. ${ }^{95}$ Furthermore, the degree of loss on a guarantee of a financial obligation can be up to the full amount of that obligation. ${ }^{96}$ The risk analysis on guarantees might not always take that degree of loss into account. ${ }^{97}$

The failure rate of financial guarantors confirms these risks. Consider the example of insurance companies that guarantee the payment of principal and interest to investors on bonds and other debt securities. ${ }^{98}$ Of the nine such insurers operating prior to the financial crisis, all but one failed - a failure rate much higher than that of banks. ${ }^{99}$

CDS contracts fit within the category of financial guarantees. ${ }^{100} \mathrm{It}$ therefore is no surprise that scholars have labeled them as "the derivative instrument most implicated in the recent financial crisis"101

94. Steven L. Schwarcz, Keynote Address, Understanding the Subprime Financial Crisis, 60 S.C. L. REV. 549, 550-52 (2009).

95. See, e.g., Steven L. Schwarcz, Regulating Complexity in Financial Markets, 87 WASH. U. L. REV. 211, 223-24 (2009) [hereinafter Schwarcz, Regulating Complexity in Financial Markets]; see also infra notes 193-95 and accompanying text (illustrating why it often is difficult to anticipate correlations in advance and why hidden correlations are only observable when there is full appreciation of the underlying variables).

96. Robert C. Merton \& Zvi Bodie, On the Management of Financial Guarantees, 21 FIN. MGMT. 87, 91 (1992) ("The guarantor firm bears the full downside risk as if it were the owner of the collateral assets.”); see also PRUDENTIAL FIN., INC., 2014 ANNUAL REPORT 206 (2015), http:/ /www3.prudential.com/annualreport/report2015/annual/images/Prudential-AR2014.pdf [https:// perma.cc/X6TL-Y2NT] ("The Company's maximum amount at risk under [its] credit derivatives equals the aforementioned notional amounts [i.e., principal and accrued interest on the underlying obligations on which Prudential sold credit protection] and assumes the value of the underlying referenced securities [i.e., their principal and interest payable thereunder] become[s] worthless.").

97. See generally Merton \& Bodie, supra note 96 (describing risk-management methods for financial guarantors and the methods' associated difficulties).

98. See, e.g., D. Dulani Jayasuriya, Icarus of the 21st Century: The Rise and Fall of Monoline/Bond Insurers 2 (Jan. 18, 2019) (unpublished manuscript), https://ssrn.com/ abstract=3318631 [https://perma.cc/P6N2-XGMT].

99. Id. at 19-26. Data from the Federal Deposit Insurance Corporation ("FDIC") show that twenty-five banks failed in 2008, 140 failed in 2009, and 157 failed in 2010. Quarterly Banking Profile, 5 FDIC Q., no. 4, 2011, at 5 tbl.I-A, https://www.fdic.gov/bank/analytical/quarterly/2011vol5-4/fdic-quarterly-vol5no4.pdf [https://perma.cc/AES8-P3XD]. For the years of 2008, 2009, and 2010, there were 8305,8012 , and 7658 banks reporting to the FDIC, respectively, for failure rates of 0.3 percent, 1.7 percent, and 2.1 percent, respectively. Id.

100. See supra notes 61-63 and accompanying text (discussing why CDS contracts epitomize financial guarantees).

101. See, e.g., Sean J. Griffith, Substituted Compliance and Systemic Risk: How To Make a Global Market in Derivatives Regulation, 98 MINN. L. REV. 1291, 1299 (2014); see also Michael 
as well as the riskiest type of derivatives contract. ${ }^{102}$ AIG's near failure, ${ }^{103}$ for example, resulted from defaults under CDS contracts. ${ }^{104}$ More recently, JP Morgan Chase lost $\$ 6$ billion betting on the strength of CDS instruments. ${ }^{105}$

\section{B. Having One or More Systemically Important Counterparties Can Magnify CDS Risk}

Financial-guarantee risk is magnified when the guarantee contract has one or more systemically important counterparties. And, notably, CDS contracts often have at least one such counterparty. ${ }^{106}$ This magnifies the risk because systemically important counterparties tend

Greenberger, Too Big To Fail U.S. Banks' Regulatory Alchemy: Converting an Obscure Agency Footnote into an "At Will" Nullification of Dodd-Frank's Regulation of the Multi-Trillion Dollar Financial Swaps Market 29-30 (Inst. for New Econ. Thinking, Working Paper No. 74, 2018), https://www.ineteconomics.org/uploads/papers/WP_74.pdf [https://perma.cc/NBP3-7FKQ] (arguing that "CDS (especially "naked' CDS) fomented" the financial crisis, and citing "economists, regulators, investigating commissions, market observers, and financial columnists" who agree that CDS "played" a "central role" in that crisis (footnotes omitted)).

102. Yesha Yadav, The Problematic Case of Clearinghouses in Complex Markets, 101 GEO. L.J. 387, 391 (2013).

103. See supra notes 10-11 and accompanying text (discussing the use of derivatives by AIG and its near failure).

104. See, e.g., Lubben, supra note 10, at 320 (observing that CDS investors commenced collection actions against AIG because of the collapse of the MBS market, which threatened AIG's financial integrity).

105. JPMorgan Chase Whale Trades: A Case History of Derivatives Risks and Abuses: Hearing Before the Permanent Subcomm. on Investigations of the S. Comm. on Homeland Sec. \& Governmental Affs., 113th Cong. 4 (2013) (statement of Sen. Carl Levin). The bank's London desk executed a series of complicated trades that would profit if corporate bond indexes rose, with the intention of hedging itself from the risk of default on the loans it held on its books. See Daniel Wilchins \& Carrick Mollenkamp, JPMorgan's Future Losses at the Mercy of an Obscure Index, REUTERS (May 17, 2012, 12:21 AM), https://reut.rs/JPOPkZ [https://perma.cc/F5573LQK]. One index, the Markit CDX NA IG Series 9, maturing in 2017, was a portfolio of CDS contracts. Id. That index tracked the credit quality of 121 high-quality bond issuers, including Kraft Foods and Walmart. Id. When JP Morgan's trades started losing money, many other traders began taking the opposite position. They hoped to profit from JPMorgan's loss, thus compounding it. Id.

106. See Christopher S. Dwight, Note, Missed (Inter)Connections: Proposed Revisions to the Federal Reserve's Approach to Financial Stability Analysis Under the Bank Holding Company Act, 18 N.C. BANKING INST. 599, 603 (2014) (arguing that derivatives counterparties often engage in multiple transactions with systemically important firms); Franklin R. Edwards \& Edward R. Morrison, Derivatives and Systemic Risk: What Role Can the Bankruptcy Code Play?, in SYSTEMIC FinanCIAl CRISES: Resolving LaRge BANK Insolvencies 347, 351 (Douglas D. Evanoff \& George G. Kaufman eds., 2005) (finding that relatively few banks control the derivatives market and that seven U.S. banks hold more than 95 percent of the U.S. national derivatives exposure). 
to do business with like counterparties, ${ }^{107}$ creating an interconnectedness that drives systemic risk. ${ }^{108}$ The failure of a systemically important counterparty can lead to a domino effect, triggering a chain of failures. ${ }^{109}$

The U.S. government bailed out AIG, a systemically important protection seller on multiple CDS contracts, to prevent such a domino effect. ${ }^{110}$ The failure of Lehman Brothers, another systemically important firm, is widely believed to have precipitated the financial crisis. ${ }^{11}$ Consistent with these observations, economists at the New York Federal Reserve Bank and finance scholars at Yale contend that a derivatives contract can "create[] systemic risk" when a default "seriously impair[s] the financial condition of one or more of its [systemically important] counterparties." 112

107. See, e.g., Mila Getmansky, Giulio Girardi \& Craig Lewis, Interconnectedness in the CDS Market, 72 FIN. ANALYSTS J. 62, 76-78 (2016) ("Overall, the interconnectedness of the CDS market is largely attributable to end users that transact with a relatively small number of dealers, who then manage net exposures by trading among themselves.").

108. See Steven L. Schwarcz, Derivatives and Collateral: Balancing Remedies and Systemic Risk, 2015 U. ILL. L. REV. 699, 704 [hereinafter Schwarcz, Derivatives and Collateral]; see also Getmansky, Girardi \& Lewis, supra note 107, at 76-79 ("The picture that emerges is one of a network that is relatively robust to the disappearance of a random node but potentially vulnerable if a few highly connected dealers should fail."). This interconnectedness creates risk regardless of the position of a systemically important counterparty: if a protection seller, the counterparty might fail-like AIG-because it cannot make the payments; if a protection buyer, the counterparty might fail because it will not get paid.

109. James Bullard, President \& Chief Exec. Officer of Fed. Rsrv. Bank of St. Louis, Systemic Risk and the Macroeconomy: An Attempt at Perspective (Oct. 2, 2008), https://www.stlouisfed.org/ from-the-president/speeches-and-presentations/2008/systemic-risk-and-the-macroeconomy-anattempt-at-perspective [https://perma.cc/JDD3-RJBM]. But see Paul Glasserman \& H. Peyton Young, Contagion in Financial Networks, 54 J. ECON. LITERATURE 779, 826 (2016) (reviewing literature on financial contagion and concluding that more research is needed to understand how risks are transmitted); Rizwaan Jameel Mokal, Liquidity, Systemic Risk, and the Bankruptcy Treatment of Financial Contracts, 10 BROOK. J. CORP. FIN. \& COM. L. 15, 15-16 (2015) (arguing that counterparty failure may not be a significant source of systemic risk, and that the "'domino' contagion view of distress . . . is theoretically flawed and empirically false").

110. William K. Sjostrom Jr., The AIG Bailout, 66 WASH. \& LEE L. REV. 943, 977-79 (2009).

111. See, e.g., Viral Acharya, Thomas Philippon, Matthew Richardson \& Nouriel Roubini, The Financial Crisis of 2007-2009: Causes and Remedies, 18 FIN. MKTS. INSTS. \& INSTRUMENTS 89, 93 (2009) (stating that Lehman's bankruptcy "led to the near collapse of the financial system"); Laurence Ball, The Fed and Lehman Brothers: Introduction and Summary 7-8 (Nat'l Bureau of Econ. Rsch., Working Paper No. 22410, 2016), https://www.nber.org/papers/w22410.pdf [https:// perma.cc/VCA6-AZS7] (discussing Lehman's collapse).

112. Rosalind Z. Wiggins \& Andrew Metrick, The Lehman Brothers Bankruptcy G: The Special Case of Derivatives, 1 YALE J. FIN. CRISIS 151, 167 (2019) (quoting with approval a New York Federal Reserve study). 


\section{The Absence of an Insurable-Interest Requirement Can Further Magnify CDS Risk}

Currently, a CDS protection buyer or seller is not required to have an "insurable interest" in the financial obligation for which it buys or sells protection. ${ }^{113} \mathrm{~A}$ CDS contract for which the protection buyer lacks such an insurable interest is often called a "naked" CDS. ${ }^{114}$ Naked CDS contracts have heightened risk for two related reasons. First, in theory, they can be used purely for speculation, ${ }^{115}$ which is thought to magnify risk by creating an unlimited multiplier effect:

113. Christopher L. CUlp, ANDria VAn DER Merwe \& BetTina J. STÄRKLE, CRedit DEFAULT SWAPS 144-45 (2018); see also Stout, supra note 2, at 6 (making the same observation). Likewise, there currently is no legal requirement that a beneficiary of a guarantee have an insurable interest in the financial obligation that is guaranteed. See, e.g., Stout, supra note 2, at 21 (describing the enactment of the Commodities Futures Modernization Act of 2000, which provided the "wholesale removal of centuries-old restraints on off-exchange derivatives speculation").

114. See, e.g., Gretchen Morgenson, Naked Came the Speculators, N.Y. TIMES (Aug. 17, 2008), https://www.nytimes.com/2008/08/10/business/10gret.html [https://perma.cc/DEQ2ADC6]. This Article avoids computational details in defining what constitutes a naked CDS. An actual CDS contract might only partially protect an insurable interest. See 111 CONG. REC. 3944 (2010) (proposal of Sen. Byron Dorgan) (proposing an amendment to the Restoring American Financial Stability Act to ban naked CDS transactions and distinguishing between CDS and naked CDS contracts on the basis of two criteria: whether the protection buyer owned valid credit instruments that matched the CDS's reference entity, and whether the value of the protection buyer's credit instruments was equal to or greater than the notional amount of the CDS). Without precisely comparing the value of the protection buyer's insurable interest to the amount of CDS protection purchased, this author's visceral reaction is that value that is reasonably equivalent to that amount should avoid being naked. See infra note 118 and accompanying text (observing that the insurable-interest requirement merely dictates that an insured derive a benefit from the continued existence of the insured entity). Clearly, for example, one thousand dollars of CDS protection sold to an owner of one hundred dollars of bonds should be naked CDS protectionat least to the extent of nine hundred dollars of the CDS contract. Cf. Lynch, supra note 5, at 7677 (observing that it "is possible-and, indeed, common-for a counterparty to a single derivatives contract to be both hedging a pre-existing risk and speculating simultaneously").

115. See, e.g., Sheri Markose, Simone Giansante \& Ali Rais Shaghaghi, 'Too Interconnected To Fail' Financial Network of US CDS Market: Topological Fragility and Systemic Risk, 83 J. ECON. BEHAV. \& ORG. 627, 631 (2012) ("The so-called naked CDS buy position is, therefore, a speculative one undertaken for pecuniary gain from either the cash settlement in the event of a default or a chance to offset the CDS purchase with a sale at an improved CDS spread."). However, even a naked CDS contract can be viewed as a traditional guarantee because guarantees, unlike insurance contracts, do not need to have an "insurable interest" to be valid. See supra note 113; cf. Stout, supra note 2, at 4 (observing that, prior to the twentieth century, the common law applied a doctrine called "the rule against difference contracts" to discourage derivatives that did not serve a hedging purpose by treating them as unenforceable wagers). But see Stout, supra note 2, at 14 ("Despite judicial concern about the negative economic impacts of gambling, the common law did not prohibit parties who wanted to wager through speculative derivative contracts from doing so."). 
[B]etting on market events can create new risk that is an order of magnitude larger than the risk associated with the underlying market phenomenon. A highly confident derivatives speculator, for example, might happily sell $\$ 1,000,000$ in CDS contracts on a $\$ 100,000$ bond. ${ }^{116}$

Second, naked CDS contracts also are thought to magnify risk by fostering moral hazard. ${ }^{117}$ At common law, there is an insurableinterest requirement mandating that a person who takes out insurance must derive some benefit from the continued existence of the insured person or property. ${ }^{118}$ This requirement helps reduce moral hazard by decreasing the incentive for the person taking out the insurance to kill the insured person or destroy the insured property in order to collect on the insurance policy. ${ }^{119}$

Without such a requirement, naked CDS contracts are susceptible to similar dangers. Professor Timothy Lynch argues, for example, that purely speculative derivatives "increase[] the opportunities to engage in societally injurious regulatory arbitrage and may create moral hazards and conflicts of interest for corporate executives and corporate creditors." ${ }^{120}$ Industry observer Nathaniel Dutt argues that a naked CDS "will reduce an incentive to monitor or accurately appraise

116. Stout, supra note 2, at 10.

117. Charles W. Murdock, The Dodd-Frank Wall Street Reform and Consumer Protection Act: What Caused the Financial Crisis and Will Dodd-Frank Prevent Future Crises?, 64 SMU L. REV. 1243, 1319-20 (2011); cf. Jerome A. Madden, A Weapon of Mass Destruction Strikes: Credit Default Swaps Bring Down AIG and Lehman Brothers, 5 AM. U. BUS. L. BRIEF 15, 20 (2008) (arguing that at least some of AIG's use of CDS contracts included naked CDS contracts).

118. Alexander Charap, Minimizing Risks, Maximizing Flexibility: A New Approach to Credit Default Swap Regulation, 11 J. Bus. \& SEC. L. 127, 156 (2011) ("The insurable interest requirement is a common law doctrine which dictates that an insured must derive a benefit, financial or otherwise, from the continued existence of the insured entity. Absent an insurable interest, an insurance contract may be void.").

119. Id. at 157; Lynch, supra note 5, at 49 ("The primary reason for implementing the insurable interest rule is that without it, an undesirable moral hazard may be created. A nonhedging policyholder would have incentive to murder an insured person or destroy insured property."). The problem of moral hazard is that "persons protected from the negative consequences of their risky actions will be tempted to take more risks." Steven L. Schwarcz, Too Big To Fool: Moral Hazard, Bailouts, and Corporate Responsibility, 102 MINN. L. REV. 761, 761 (2017) [hereinafter Schwarcz, Too Big To Fool].

120. Timothy E. Lynch, Gambling by Another Name; The Challenge of Purely Speculative Derivatives, 17 STAN. J.L. BUS. \& FIN. 67, 74 (2011) [hereinafter Lynch, Gambling by Another Name]. But compare Stout, supra note 2, at 10 (arguing that speculative derivatives trading is a zero-sum game that exposes both parties to "new risks without providing any compensating increase in aggregate returns"), with MICHAEL S. BARR, HOWELL E. JACKSON \& MARGARET E. TAHYAR, FinANCIAL REgUlATION: LAW AND POLICY 1165 (2d ed. 2018) (observing that any "derivative's payoff structure is normally zero-sum"). 
certain risks." ${ }^{121}$ For example, he suggests that "a bank that makes loans and then purchases a CDS to reduce the risk of a borrower default will have a reduced incentive to monitor the loans." ${ }^{122}$ Although the CDS protection seller would thereby gain that incentive, he argues that the "bank is in the best position to" engage in that monitoring. ${ }^{123}$

In summary, derivatives are not inherently riskier than the traditional option contracts and guarantees they functionally represent. However, at least one subset of guarantees-CDS contracts with systemically important counterparties-can seriously threaten economic stability, and their speculative nature and the absence of an insurable-interest requirement can further magnify that threat.

\section{DERIVATIVES REgulation IS OFTEN FLAWED}

By starting from the flawed premise that most derivatives are uniquely risky, the consequent derivatives regulation is also often flawed. Section A shows that derivatives regulation often starts from this flawed premise, and Section B shows that such derivatives regulation, which includes aspects of the G20 regulatory scheme (and thus U.S. law, which follows that scheme ${ }^{124}$ ), can simultaneously overregulate and underregulate derivatives in ways that can inadvertently concentrate systemic risk.

\section{A. Derivatives Regulation Often Presumes that Most Derivatives Are Uniquely Risky}

By following the G20 regulatory scheme, ${ }^{125}$ U.S. derivatives regulation has shifted "from a laissez-faire paradigm to a bank regulatory paradigm focused on safety and soundness." ${ }^{26}$ To ensure safety and soundness, U.S. law requires most derivatives, often

121. Nathaniel G. Dutt, Current United States Credit Default Swap Regulatory Initiatives: A New World Standard of Just a Ploy, 16 ILSA J. INT'L \& COMP. L. 169, 184 (2009).

122. Id. It is questionable, however, whether that example represents naked CDS if the bank is buying CDS protection on a loan it still owns.

123. Id.

124. See supra notes $23-24$ and accompanying text.

125. See supra notes 23-24 and accompanying text (introducing the G20 and its regulatory scheme for derivatives).

126. Arthur W.S. Duff \& David Zaring, New Paradigms and Familiar Tools in the New Derivatives Regulation, 81 GEO. WASH. L. REV. 677, 678 (2013). 
regardless of their type ${ }^{127}$ and contractual counterparties, ${ }^{128}$ to be
cleared $^{129}$ and settled ${ }^{130}$ through central counterparties ("CCPs"). ${ }^{131}$

127. Compare supra note 31 and accompanying text (observing that market participants recognize four types of derivatives contracts), with Paul M. McBride, The Dodd-Frank Act and OTC Derivatives: The Impact of Mandatory Central Clearing on the Global OTC Derivatives Market, 44 INT'L L. 1077, 1102 (2010) (arguing that “[b]y expansively defining the terms Swap and Security-Based Swap to include most options and swap transactions, along with any agreement that subsequently becomes commonly known as a swap," the Dodd-Frank Act "ensures that the clearing requirements are broadly applicable and capture the different types of derivative products that currently exist or that may arise in the future").

128. The Financial Stability Board suggests that regulators should consider exempting derivatives without systemically important counterparties from central clearing requirements:

The impact of an entity on financial stability from OTC derivatives is likely to depend on the extent of their activity. Lower levels of OTC derivatives activity, all else equal, are likely to result in a lower impact. Thus, while the financial stability benefits from central clearing by [counterparties with lower levels of derivatives activity] can still exist, the gains are likely to be smaller than those for entities in the systemic core, particularly relative to the costs .... [Standard setting bodies therefore] may merit consideration ... of [not imposing the central clearing] reforms on market participants that are not considered systemically important.

Fin. Stability Bd., Incentives to Centrally Clear Over-the-Counter (OTC) DERIVATIVES 4 (2018) [hereinafter FIN. STABILITY BD., INCENTIVES TO CENTRALLY CLEAR], https://www.fsb.org/wp-content/uploads/R191118-1-1.pdf [https://perma.cc/2F2B-5R4C]; see also Schwarcz, Derivatives and Collateral, supra note 108, at 712 ("Incongruously, the [U.S. bankruptcy law] safe harbor [for derivatives] operates independently of the size of the counterparty or its portfolio... . By failing to take systemic importance into account, the safe harbor extends well beyond its purported rationale of reducing systemic risk.").

129. Clearing is "the process of transmitting, reconciling and, in some cases, confirming transfer orders prior to settlement." EUR. CENT. BANK, GLOSSARY OF TERMS RELATED TO PAYMENT, CLEARING AND SETTLEMENT SYSTEMS 5 (2009), https://www.ecb.europa.eu/pub/pdf/ other/glossaryrelatedtopaymentclearingandsettlementsystemsen.pdf [https://perma.cc/Q2YK9EQV]. It involves identifying the obligations of the parties to the transaction. See id.

130. Settlement is "the completion of a transaction or of processing with the aim of discharging participants' obligations through the transfer of funds and/or securities." Id. at 24.

131. See, e.g., Derivatives, SEC, https://www.sec.gov/spotlight/dodd-frank/derivatives.shtml [https://perma.cc/6J52-XYRC] (explaining that Title VII of the Dodd-Frank Act and followup regulation by the Securities and Exchange Commission ("SEC") and Commodities Futures Trading Commission ("CFTC"), require that most derivatives contracts be centrally cleared through CCPs). 
CCPs are well-capitalized entities ${ }^{132}$ often associated with derivatives, commodities, or other securities exchanges. ${ }^{133}$

The goal of this central clearing requirement, which applies only to derivatives, is to reduce counterparty risk. ${ }^{134}$ By legally substituting its credit for that of the contracting parties, the $\mathrm{CCP}$ becomes the primary counterparty on both sides of the derivatives contract-for example, the buyer to every seller and the seller to every buyer. ${ }^{135}$ Central clearing thereby reduces individual counterparty risk ${ }^{136}$ by ensuring the performance of a derivatives contract even if a contracting party fails. ${ }^{137}$

Like the United States, many other countries follow the G20 regulatory scheme to require the central clearing of derivatives, often regardless of their type. ${ }^{138}$ As of mid-October 2019, for example,

132. Schwarcz, Central Clearing of Financial Contracts, supra note 66, at 1329, 1358. But see Colleen M. Baker, Regulating the Invisible: The Case of Over-the-Counter Derivatives, 85 NOTRE DAME L. REV. 1287, 1291-94 (2010) (arguing that CCPs should be even better capitalized); Paolo Saguato, The Ownership of Clearinghouses: When "Skin in the Game" Is Not Enough, the Remutualization of Clearinghouses, 34 YALE J. ON REG. 601, 604 (2017) (discussing the agency costs and risks associated with different ownership models for CCPs); Paolo Saguato, The Unfinished Business of Regulating Clearinghouses, 2020 COLUM. BUS. L. REV. 1, 55-64 (offering policy solutions to strengthen CCPs' resilience).

133. The three largest U.S. CCPs, for example, are CME Clearing Services, which provides clearing and settlement of exchange trades on the Chicago Mercantile Exchange and the Chicago Board of Trade; ICE Clear U.S., which is owned by New York Stock Exchange parent company Intercontinental Exchange; and $\mathrm{LCH}$, which is a unit of the London Stock Exchange Group. See Clearing Firms, CME GRP., https://www.cmegroup.com/clearing/financial-and-regulatorysurveillance/clearing-firms.html [https://perma.cc/TPY2-2TBE] (providing a list of clearing firms); Michelle Price, Three Biggest U.S. Clearing Houses Pass Liquidity Stress Tests: CFTC, REUTERS (Oct. 16, 2017, 12:08 AM), https://reut.rs/2idTBEd [https://perma.cc/6PJJ-A9SJ] (naming CME Clearing, ICE Clear U.S., and LCH Ltd as the three largest U.S. clearing houses).

134. Schwarcz, Central Clearing of Financial Contracts, supra note 66, at 1330; cf. Duff \& Zaring, supra note 126, at 702 (discussing the federal regulatory mandate to assure the "safety and soundness" of derivatives, regardless of their type).

135. See, e.g., PETER Norman, THE Risk CONTROLlers 7 (2011) ("By becoming the buyer to every seller and the seller to every buyer, the CCP assures completion of the trade if a trading partner defaults."); Richard Squire, Clearinghouses as Liquidity Partitioning, 99 CORNELL L. REV. 857, 862 (2014) ("The clearinghouse interposes itself between the parties, serving as the counterparty to each. Instead of selling the cattle future to Buyer, Seller sells it to the clearinghouse, which sells an identical future to Buyer."). The substitution of credit is legally referred to as a "novation," which arises when a new party assumes a payment obligation that was incurred by a debtor on a contract and the original debtor is totally released from the obligation. 66 C.J.S. Novation $\$ 1$ (2020).

136. Counterparty risk is the risk that a contracting party's default will harm other parties to the contract. NORMAN, supra note 135 , at 9.

137. Id. at 7 .

138. See generally Heckinger et al., supra note 24 (summarizing the regulatory history of the central clearing mandate for derivatives contracts). 
"[e]ighteen jurisdictions have in force comprehensive standards/criteria for determining when standardised OTC derivatives should be centrally cleared ...." "Standardized" derivatives include virtually all derivatives that are "documented on ISDA forms." 140 That is a "very low bar" because derivatives commonly are documented on those forms. ${ }^{141}$

U.S. and foreign derivatives regulation that follows the G20 regulatory scheme thus requires most derivatives, but no other type of financial instrument, to be centrally cleared to reduce their risk. Effectively, therefore, that regulation treats most derivatives as uniquely risky.

\section{B. Derivatives Regulation that Starts from that Flawed Premise Is Also Flawed}

The flawed premise that most derivatives are uniquely risky has given rise to "a derivatives regulatory regime that often appears confusing, incomplete, contradictory, greatly subject to interpretation, incapable of addressing derivatives innovation, and even at times, simply irrational or incomprehensible." ${ }^{142}$ Existing regulation not only overregulates derivatives in some ways and underregulates them in others but also concentrates-and thereby, inadvertently may increase-systemic risk.

The central clearing requirement, for example, overregulates derivatives because it applies to most derivatives, often regardless of their type or their counterparties. ${ }^{143}$ Existing regulation also underregulates derivatives by inadequately addressing what this Article later describes as systemically risky CDS contracts. ${ }^{144}$

139. Fin. StABILITY BD., OTC Derivatives MARKET REForms: 2019 Progress RePORT ON IMPLEMENTATION 2 (2019), https://www.fsb.org/wp-content/uploads/P151019.pdf [https:// perma.cc/JB8Z-MAR8] ("In a few of these 18 jurisdictions a wider range of products is now subject to mandatory clearing.").

140. Schwarcz, Central Clearing of Financial Contracts, supra note 66, at 1372.

141. Id.

142. Lynch, supra note 5, at 13 .

143. See supra notes $127-28$ and accompanying text.

144. See infra Parts IV.B \& IV.C; see also Fin. STABILITY BD., REVIEW OF OTC DERIVATIVES MARKET REFORMS EFFECTIVENESS AND BROADER EFFECTS OF THE REFORMS § 3.2.1, at 12 (2017), https://www.fsb.org/wp-content/uploads/P290617-1.pdf [https://perma.cc/ V44W-6D7D] (reporting that the rate of central clearing has increased more for interest-rate derivatives than for CDS contracts and estimating the global rate of CDS central clearing was only 28 percent at end-December 2016, although that represents a sharp increase from 5 percent at end-June 2009). But see Houman B. Shadab, Counterparty Regulation and its Limits: The 
Recognizing that CDS derivatives were the type most responsible for causing the financial crisis, several governmental organizations contemplated specifically regulating the CDS market. ${ }^{145}$ Ironically, the faulty perception that most derivatives are uniquely risky diverted regulatory attention from CDS contracts alone to derivatives generally. ${ }^{146}$

Although intended to reduce risk ${ }^{147}$ central clearing could inadvertently increase systemic risk by "shift[ing] counterparty risk" from individual counterparties to the $\mathrm{CCP}$, thereby concentrating the risk. ${ }^{148}$ Even the Financial Stability Board, the G20 body that originally proposed the central clearing requirement, is becoming concerned that central clearing might increase, rather than reduce, systemic risk. ${ }^{149}$

The G20 regulatory scheme also proposes minimum margin requirements for non-centrally cleared derivatives. ${ }^{150}$ "Posting margin"

Evolution of the Credit Default Swaps Market, 54 N.Y.L. SCH. L. REV. 689, 705 (2010) (arguing that CDS risk-management practices have always been "generally adequate," and that "the broader infrastructure of the CDS market [has always] remained generally stable" except for "the very small portion of the market whereby an unregulated subsidiary or affiliate of an insurance company [presumably referring to AIG] sold too much CDS protection referencing certain banking institutions' mortgage-backed CDOs").

145. See Thomas Lee Hazen, Filling a Regulatory Gap: It Is Time To Regulate Over-theCounter Derivatives, 13 N.C. BANKING INST. 123, 124 (2009) (discussing efforts by the SEC and the President's Working Group on the financial crisis to centralize the CDS market and plans, later dropped, by New York State to regulate CDS contracts as insurance).

146. See, e.g., Kristin N. Johnson, Things Fall Apart: Regulating the Credit Default Swap Commons, 82 U. Colo. L. REV. 167, 235-41 (2011) (describing the Dodd-Frank Act's wide regulatory ambit that reaches not only CDS derivatives but the OTC derivatives market as a whole).

147. See supra notes $135-37$ and accompanying text.

148. Anabtawi \& Schwarcz, Regulating Systemic Risk, supra note 88, at 1395; see also Mark J. Roe, Clearinghouse Overconfidence, 101 CALIF. L. REV. 1641, 1692 n.123, 1697 (2013) (collecting sources on whether central clearing reduces or merely shifts counterparty risk from individual counterparties to the CCPs); Ivana Ruffini, Central Clearing: Risks and Customer Protections, 39 ECON. PERSP. 90, 97 (2015) (observing that central clearing creates systemic costs by concentrating counterparty risk in the CCPs); Yadav, supra note 102, at 389 (challenging the "regulatory and academic consensus" by arguing "that clearinghouses, as presently conceived, are sorely ill-equipped to contend with the complex legal and economic risks of the credit derivative").

149. See Fin. Stability BD., InCEntives to Centrally Clear, supra note 128, at 3 (observing that "[s]urvey responses and market outreach are also consistent with a view that concentration in clearing service provision could amplify the consequences of the failure" of a "major" derivatives counterparty). Economists also argue that the central clearing of CDS transactions could reduce netting efficiency if done separately. Darrell Duffie \& Haoxiang Zhu, Does a Central Clearing Counterparty Reduce Counterparty Risk?, 1 REV. AsSET PRICING STUD. 74, 90 (2011).

150. Over-The-Counter Derivatives, supra note 24. 
refers to providing securities or other liquid assets as collateral to secure a counterparty's obligation to settle a derivatives contract. For example, a CDS protection seller that would be obligated to pay $\$ 1$ million if the CDS contract were settled on that day might, if the contract so provided, be required to provide the protection buyer with (at least) $\$ 1$ million of securities to collateralize that obligation. Presuming that most derivatives are uniquely risky, minimum margin requirements are supposed to ensure that derivatives counterparties who are unprotected by central clearing at least are adequately protected by collateral. ${ }^{151}$ Margin requirements, however, can be a mixed blessing. Although they can help to protect against counterparty default, ${ }^{152}$ margin requirements also can lead to unpredictable liquidity-funding demands if the counterparty lacks sufficient liquid assets to post. ${ }^{153}$ Indeed, AIG's near failure resulted from its inability to satisfy CDS margin requirements. ${ }^{154}$

More significantly, it is dubious whether regulators should impose formulaic $^{155}$ margin requirements on sophisticated derivatives counterparties who presumably know best how to control their own risk and have incentives to do so. ${ }^{156}$ Those counterparties can, and

151. See, e.g., BASEl COMM. ON BANKING SUPERVISION \& BD. OF THE INT'L ORG. OF SEC. COMM'NS, MARGIN REQUIREMENTS FOR NON-CENTRALly CLEARED DERIVATIVES 3 (2015) [hereinafter BASEL COMM. ET AL., MARGIN REQUIREMENTS], https://www.bis.org/bcbs/publ/ d317.pdf [https://perma.cc/GY8A-3GYN]; COMMODITY FUTURES TRADING COMM'N \& SEC, JOINT REPORT ON INTERNATIONAL SWAP REGULATION 25 (2012), https://www.sec.gov/news/ studies/2012/sec-cftc-intlswapreg.pdf [https://perma.cc/ZK5Q-KA54].

152. See Schwarcz, Regulating Complexity in Financial Markets, supra note 95, at 232-33 (discussing how margin requirements can help to protect against counterparty default).

153. Id.; see also Diana Milanesi, Risk/Benefit Analysis of Central Clearing of Over-theCounter (OTC) Derivatives and a Chaos Theory-Based Perspective on Clearing Mandates 197 (Summer 2017) (Ph.D. dissertation, University of California, Berkeley), https://escholarship.org/ content/qt8nz4n9z9/qt8nz4n9z9.pdf [https://perma.cc/F6N5-HS6P]; Craig Pirrong, The Inefficiency of Clearing Mandates, CATO INST. 3 (July 21, 2010), https://object.cato.org/sites/ cato.org/files/pubs/pdf/PA665.pdf [https://perma.cc/3CEZ-UDKH] (observing that "imposing margin requirements" can limit risk but is "socially costly").

154. See supra note 10. But cf. Patrick Fitzgerald \& Marie Beaudette, Lehman Wasn't Felled by JP Morgan Collateral Calls, WALL ST. J. (May 17, 2012, 2:46 PM), https://www.wsj.com/articles/ SB10001424052702303360504577410353589465814 [https://perma.cc/59N7-7VYQ] (reporting the Treasury Secretary's position that "the government takeover of Fannie Mae and Freddie Mac in the days before Lehman's Sept. 15, 2008, Chapter 11 filing resulted in institutional investors and clearing banks 'pulling away' from financial institutions, including Lehman, and was the real reason that the investment bank entered a death spiral").

155. For instructions on how to calculate these margin requirements, see 17 C.F.R. $\$ 23.154$ (2020)

156. Although sophisticated derivatives counterparties may know "best," they do not necessarily know perfectly. 
normally do, balance their own costs and benefits when contracting about their rights and obligations to post margin. ${ }^{157}$ In this regard, the G20's minimum margin requirements for non-centrally cleared derivatives parallel the G20's questionable risk-retention, or "skin-inthe-game," requirements for securitization transactions. ${ }^{158}$ Those securitization requirements either overlook, or ignore, that it was always common practice for sponsors of securitizations to retain substantial risk on the underlying loans they sold. ${ }^{159}$ Indeed, other securitization counterparties demanded the sponsors do so, as a matter of commercial reality, to protect themselves. ${ }^{160}$ Thus, the real-world impact of the G20's risk-retention requirements may well be de minimis, at best. ${ }^{161}$

At worst, however, the false appearance of a regulatory "solution" can be dangerous. ${ }^{162}$ The risk-retention requirement might give the appearance of solving the problem of securitization's abuses, but it

157. See, e.g., INT'L SWAPS AND Derivatives Ass'N, LEGAL GUIDELINES For SMART DeRIVATIVES CONTRACTs: COllateral 15 (2019), https://www.isda.org/a/VTkTE/LegalGuidelines-for-Smart-Derivatives-Contracts-Collateral.pdf [https://perma.cc/M2UL-GFDP] (stating that "[p]arties may wish to exchange collateral even where there is no obligation under any relevant regulatory regime to do so," and providing documentation for parties to do so). In theory, one might conceive counterparty A demanding less collateral than socially optimal from counterparty B because counterparty A would be unconcerned about externalities if it ends up failing due to counterparty B's default. See infra note 172 and accompanying text. In practice, though, any such collateral deficiency should be de minimis, if not zero, because counterparty A commonly would demand, and counterparty B commonly would grant, sufficient collateral to ensure payment if counterparty B defaults. See Awrey, Split Derivatives, supra note 5, at 500 (discussing how derivatives counterparties use collateral to help protect themselves).

158. See, e.g., Andrew M. Faulkner, Despite Challenges, Risk Retention Rules Set To Impact All Asset-Backed Securities by End of 2016, SKADDEN ARPS SLATE MEAGHER \& Flom LLP (Apr. 26, 2016), https://www.skadden.com/insights/publications/2016/04/despite-challenges-riskretention-rules-set-to-imp [https://perma.cc/52QC-QJJ5]. The risk-retention requirements were mandated by a G20 summit in September 2009. See G20 Leaders Statement: The Pittsburgh Summit, TRINITY COLL. UNIV. TORONTO (2019), http://www.g20.utoronto.ca/2009/2009communique0925.html [https://perma.cc/W4M7-GNT3].

159. See Ryan Bubb \& Prasad Krishnamurthy, Regulating Against Bubbles: How Mortgage Regulation Can Keep Main Street and Wall Street Safe - from Themselves, 163 U. PA. L. REV.1539, 1589-93 (2015) (disputing the notion that risk-retention requirements created moral hazard and thus contributed to the financial crisis of 2007-2008).

160. Id.

161. Mathew C. Turk, Securitization Reform after the Crisis: Regulation by Rulemaking or by Settlement?, 37 REV. BANKING \& FIN. L. 861, 880, 901 (2018).

162. See Steven L. Schwarcz, Securitization: Ten Years After the Financial Crisis, 37 ReV. BANKING \& FIN. L. 757, 762 (2018) (observing that risk retention inadvertently can mislead securitization investors into thinking they are buying something that is safer than it actually is). 
does not provide a real solution. ${ }^{163}$ As this Article argues, ${ }^{164}$ regulatory solutions to the derivatives problem are likely very different than imposing artificial margin requirements on sophisticated counterparties.

Part IV next analyzes how to design more targeted and effective derivatives regulation. Imperfect as the G20 scheme may be, replacing it is politically unrealistic. Therefore, this Article designs targeted derivatives regulation to complement and enhance the G20 scheme. This follows the well-respected approach of building normative legal improvements onto an established positive law foundation. ${ }^{165}$

\section{Designing Targeted Derivatives Regulation}

Targeted derivatives regulation should focus on regulating CDS contracts with systemically important counterparties (hereinafter, "systemically risky CDS contracts"), which can seriously threaten economic stability. ${ }^{166}$ Designing such regulation requires a normative framework suitable for regulating financial instruments. Section A builds that framework. Section B then uses it to analyze how to regulate systemically risky CDS contracts that guarantee insurable interests. Thereafter, Section $\mathrm{C}$ uses the same framework to analyze how to regulate naked systemically risky CDS contracts-namely, those that do not guarantee insurable interests. ${ }^{167}$ Recognizing that even the best regulation cannot eliminate CDS risk, Section D examines how to regulate the failures that inevitably will occur. Finally, the Appendix to this Article proposes model language to implement these regulatory recommendations.

\section{A. Building a Normative Framework for Financial Regulation}

Cost-benefit analysis provides a standard justification for financial regulation-the benefits of the proposed regulation should be

163. See id. at 760-69 (examining how to fix securitization's abuses and rebuild confidence).

164. See infra Part IV (analyzing how to design targeted derivatives regulation).

165. See, e.g., Steven L. Schwarcz, Empowering the Poor: Turning De Facto Rights into Collateralized Credit, 95 Notre DAME L. Rev. 1, 7 n.32 (2019).

166. See supra Part II.B. CDS contracts that lack any systemically important counterparties should be regulated like ordinary financial guarantees. However, financial guarantee risk is magnified when the guarantee contract has one or more systemically important counterparties. Id.

167. See supra note 114 and accompanying text (defining naked CDS contracts as those for which the protection buyer lacks an insurable interest). 
expected to exceed its costs. ${ }^{168}$ This presents a puzzle, though, when applied to sophisticated financial firms that engage in derivatives transactions generally, much less systemically risky CDS transactions. Those firms presumably know best how to control their own risk. They also have incentives to control risk to protect their investors. If those firms govern themselves accordingly, regulation appears to be unjustified because it would not provide any net benefits. Perhaps for these reasons, bank regulation - which likewise involves sophisticated financial firms that know how, and have incentives, to control risk"rarely mandates a specific way [for banks] to mitigate risk, [that is,] whether to take out insurance or to take assets as collateral etc." ${ }^{169}$

However, recognizing that the essential purpose of financial regulation is to correct market failures can solve this puzzle. ${ }^{170}$ Sophisticated financial firms that perfectly control their risk-taking to protect investors still might harm other parties, including customers, contractors, and even members of the public. ${ }^{171}$ This third-party harm represents a market failure, known as an externality. ${ }^{172}$

Corporate governance law does not normally require firms to control these. ${ }^{173}$ Instead, regulation and tort law customarily are used to control material externalities. For example, government deposit insurance is commonly thought to distort a deposit-taking bank's risk-

168. See, e.g., Eric A. Posner \& E. Glen Weyl, Benefit-Cost Paradigms in Financial Regulation, 43 J. LEG. STUD. 1, 3 (2014) (arguing that financial regulation should be subject to cost-benefit analysis); Cass R. Sunstein, Financial Regulation and Cost-Benefit Analysis, 124 YALE L.J. F. 263, 263 (2015) ("Cost-benefit analysis is best understood as a way for agencies to ensure that their decisions are informed."); see also Cass R. Sunstein, Cost-Benefit Analysis and the Environment, 115 ETHICS 351, 354 (2005) (defending the use of cost-benefit analysis for environmental regulation).

169. Schwarcz, Central Clearing of Financial Contracts, supra note 66, at 1363 \& n.197 (citing Peter O. Mülbert, Managing Risk in the Financial System, in THE OXFORD HANDBOOK OF FinANCIAL REgulation 365, 395 (Niamh Moloney, Eilís Ferran \& Jennifer Payne eds., 2015)).

170. Id. at 1363 \& n.198 (first citing DAVID GOWLAND, THE REGULATION OF FINANCIAL Markets IN THE 1990s, at 21 (1990); then citing PAUl A. SAMUElson \& William D. NORDHAUS, ECONOMICS 756 (15th ed. 1995)).

171. Steven L. Schwarcz, Misalignment: Corporate Risk-Taking and Public Duty, 92 NOTRE DAME L. REV. 1, 4-5 (2016) [hereinafter Schwarcz, Misalignment].

172. Although economists often categorize externalities as a type of market failure, externalities more precisely are caused by market failures - in this case, risk-taking that causes uninternalized externalities. Steven L. Schwarcz, Regulating Shadows: Financial Regulation and Responsibility Failure, 70 WASH. \& LEE L. REV. 1781, 1799-1800 (2013).

173. Under the norm of shareholder primacy, firm managers should act in the interests of their investors. This author has questioned whether strict shareholder primacy should apply to the governance of systemically important firms, or whether managers of those firms should have some form of a public governance duty, see generally Schwarcz, Misalignment, supra note 171. 
taking because, if the bank fails as a result of risk-taking, much of the cost of its failure would be externalized onto the government and taxpayers. ${ }^{174}$ To help correct that distortion and control externalities, regulators commonly impose capital requirements on banks. ${ }^{175}$

This same regulatory framework can inform the regulation of systemically risky CDS contracts. The law does not purport to-nor should it-regulate all risky contracting. Absent paternalism, which is inappropriate to protect the (mostly) sophisticated parties to systemically risky CDS contracts, the purpose of regulating those CDS contracts should be to control material externalities. Even with sophisticated financial firms as counterparties, systemically risky CDS contracts could cause such externalities - a systemically important protection seller's default leading to its failure, or a protection seller's default causing a systemically important protection buyer's failure, could cause a financial collapse that harms the real economy. ${ }^{176}$ Regulation that helps to control these externalities is justified, then, if its benefits can be expected to exceed its costs. ${ }^{177}$

\section{B. Regulating Systemically Risky CDS Contracts that Guarantee Insurable Interests}

Next, this Section considers possible regulatory approaches, including their costs and benefits, to help control the material externalities caused by systemically risky CDS contracts, particularly those contracts that guarantee insurable interests. As a threshold observation, the size of the CDS market appears to justify appropriate

174. See, e.g., Schwarcz, Central Clearing of Financial Contracts, supra note 66, at 1363 \& n.200 (noting "that '[a] financial safety net constituted by deposit insurance' can lead to market failure because '[i]n good times, bank shareholders do well, while in extremely bad times the insurance fund bails out the bank's depositors and debtholders"' (alterations in original) (quoting Robert L. Hetzel, Should Increased Regulation of Bank Risk-Taking Come from Regulators or from the Market?, 95 ECON. Q. 161, 166 (2009))).

175. Id. at 1363 \& n.201 (highlighting scholarship determining "that bank capital regulation is necessary 'to reduce the negative externalities resulting from government-imposed deposit insurance"” (quoting George J. Benston \& George G. Kaufman, The Appropriate Role of Bank Regulation, 106 ECON. J. 688, 688, 694-96 (1996))).

176. See supra notes 10-11,108-12 and accompanying text (discussing the near failure of AIG and the consequences of a systemically important firm's failure).

177. See supra note 168 and accompanying text. Cost-benefit analysis effectively constitutes a Kaldor-Hicks efficiency analysis-in this Article's case, that the aggregate benefit to the contracting parties exceeds the aggregate harm. Steven L. Schwarcz, Rethinking Freedom of Contract: A Bankruptcy Paradigm, 77 TEX. L. REV. 515, 551-52, 561 (1999). Kaldor-Hicks is the real-world operating definition of efficiency. $I d$. at 560-61 (citing RICHARD A. POSNER, ECONOMIC ANALYSIS OF LAW $§ 1.2$, at 13-14 (5th ed. 1998)). 
regulation. Although CDS contracts constitute only a fraction of derivatives contracts, their notional amount is in the tens of trillions of dollars. ${ }^{178}$ Sections B.1-B.3 examine innovative regulatory approaches. Section B.4 then reexamines the G20 regulatory scheme's approaches.

1. Limiting Credit Exposure. Limiting the credit exposure of systemically important firms on systemically risky CDS contracts could help control externalities by reducing the likelihood that such a firm would become unable to pay its CDS obligations, leading to its default and failure. One type of credit-exposure limit-a "protection seller limit"-could restrict a systemically important protection seller's "correlated" CDS liabilities to an aggregate amount it could feasibly pay. ${ }^{179}$ A protection seller limit would control externalities by avoiding a default that causes the protection seller's failure. ${ }^{180}$ Such a limit has precedent, for example, in U.S. regulation imposing credit limits on financial guarantees represented by standby letters of credit. ${ }^{181}$

Another type of credit-exposure limit-a "protection buyer limit"-could restrict the amount of aggregate protection a systemically important firm could buy from "correlated" CDS protection sellers to an amount that would enable the firm to continue operating without being paid. ${ }^{182}$ A protection buyer limit would control externalities because a protection seller's default would not thereby

178. BIS Statistics: Charts, BIS Q. REV., Mar. 2017 annex at A1, A16, https://www.bis.org/ publ/qtrpdf/r_qt1703.pdf [https://perma.cc/29W8-A498]. The notional amount generally does not reflect the amount at risk on a derivative; it merely refers to the value of underlying assets specified in the derivatives contract. See, e.g., APANARD (PENNY) PRABHA, KeITH SAVARD \& HeAther Wickramarachi, Milken Inst., Deriving THE ECONOMIC IMPACT OF DERIVATIVES 27 (2014), https://assets1b.milkeninstitute.org/assets/Publication/ResearchReport/ PDF/Derivatives-Report.pdf [https://perma.cc/5CKQ-ANDS] ("[N]otional amounts outstanding, though a rough measure of derivatives activity, do not represent ... generally, the amount at risk." (citations omitted)). Because CDS contracts guarantee debt obligations, their notional amount is the principal plus the accrued interest outstanding on those obligations. See supra note 96.

179. See infra notes 192-95 and accompanying text (analyzing correlated CDS liabilities).

180. See supra text accompanying note 176 (observing that the failure of a systemically important firm can cause material externalities).

181. See, e.g., Boris Kozolchyk, The Emerging Law of Standby Letters of Credit and Bank Guarantees, 24 ARIZ. L. REV. 319, 332-33 (1982). Banks also must report at least the amounts of their outstanding standby letters of credit on their financial statements. 12 C.F.R. $\S 337.2(d)$ (2020).

182. See infra notes 196-99 and accompanying text (analyzing correlated CDS protection sellers). 
trigger the protection buyer's failure. ${ }^{183}$ U.S. regulation has used similar limits, for example, by imposing lending limits on banks, ${ }^{184}$ which restrict the loans repayable to the bank from any given customer to an amount that would enable the bank to continue operating without being paid. ${ }^{185}$

Several practical challenges would accompany credit exposure limits. For one, only systemically important firms would need to be regulated in this way because the failure of a non-systemically important firm should not lead to material externalities. In jurisdictions like the United States, where regulators already designate relevant firms as systemically important, this particular challenge should be minimal-although the trend under the Trump administration to retract the systemically important designation process could renew the challenge. ${ }^{186}$

Other practical challenges, such as setting protection seller limits and protection buyer limits, could be more difficult. Such limits would need to be set for each systemically important firm. ${ }^{187}$ In an analogous

183. See infra notes 196-99 and accompanying text (observing that a protection seller's default that causes a systemically important protection buyer's failure can cause material externalities).

184. See, e.g., Kenneth J. Rojc, National Bank Lending Limits-A New Framework, 40 BUS. LAW. 903, 906-07 (1985).

185. See id. at 903, 906-07 (observing that lending limits restrict national banks from lending more than the value of 15 percent of their unimpaired capital to a single customer).

186. See, e.g., Authority To Require Supervision and Regulation of Certain Nonbank Financial Companies, 84 Fed. Reg. 71,740, 71,742 (Dec. 30, 2019) (codified at 12 C.F.R. pt. 1310 app. A) (introducing new guidance that "substantially transforms" the SIFI designation process for nonbank financial institutions "to cost-effectively minimize burdens"); John Heltman, Prudential, the Last Nonbank SIFI, Sheds the Label, AM. BANKER (Oct. 17, 2018, 9:08 AM), https://www.americanbanker.com/news/prudential-the-last-nonbank-sifi-sheds-the-label [https:// perma.cc/QY74-LYEE].

187. This could be done either by regulators setting the limits by fiat or through a give-andtake process between regulators and regulated firms. Although this Article primarily discusses the former, there is some precedent for the latter. $C f$. Lori S. Bennear \& Jonathan B. Wiener, Adaptive Regulation: Instrument Choice for Policy Learning over Time 7-8 (Feb. 12, 2019) (unpublished manuscript), https://www.hks.harvard.edu/sites/default/files/centers/mrcbg/files/ Regulation \%20-\%20adaptive \%20reg\%20-\%20Bennear \%20Wiener \%20on \%20Adaptive \%20 Reg\%20Instrum\%20Choice\%202019\%2002\%2012\%20clean.pdf [https://perma.cc/478A-ATHX] (describing a process of "adaptive regulation" that "enables learning and modification of policy over time via adjustments informed by data collection and analysis"). The merits of any particular methodology designating systemically important firms are beyond the scope of this Article, but it is worth noting that identifying a methodology to correctly identify systemically important firms is itself a considerable practical challenge. An overinclusive methodology may subject firms to potentially harmful capital requirements without protecting the public from any material externalities from that firm's failure, see Schwarcz, Too Big to Fool, supra note 119, at 779, while 
context, U.S. regulators formulaically set equivalent limits ${ }^{188}$ and use the same formula for both bank standby-letter-of-credit exposure (the equivalent of this Article's protection seller limit ${ }^{189}$ ) and bank lending exposure (the equivalent of this Article's protection buyer limit ${ }^{190}$ ). For instance, "federal regulatory agencies have required banks under their jurisdiction to count standby[] [letters of credit] toward each customer's section 84 lending limits." 191

Perhaps the most difficult practical challenge would be identifying correlations. To set a protection seller limit, for example, regulators would have to identify correlated CDS liabilities. ${ }^{192}$ A systemically important firm that sells protection to different counterparties should count its CDS liabilities as correlated to the extent a particular, even if unlikely, event can synchronize their payment. Thus, although AIG sold protection to numerous unaffiliated protection buyers, it faced default when the seemingly geographically diversified MBS underlying many of those buyers' CDS contracts faced a correlated loss in value due to widespread MBS market panic. ${ }^{193}$ In retrospect, that correlation might appear to have been obvious; in reality, though, it is often

an underinclusive methodology will necessarily expose the public to unmitigated material externalities in the event of an unincluded systemically important firm's failure.

188. Cf. supra note 185 and accompanying text (referencing lending limits calculated at 15 percent of a bank's unimpaired capital).

189. See supra notes $180-81$ and accompanying text.

190. See supra notes $183-85$ and accompanying text.

191. Kozolchyk, supra note 181, at 332-33. Although it would have to be updated on a regular basis to remain accurate, a more nuanced protection buyer limit might take into account not only the financial condition but also, to the extent not already disclosed, each protection seller's contingent CDS liabilities. This could help a protection buyer assess each such protection seller's ability to perform its CDS obligations. See Houman B. Shadab, Guilty by Association? Regulating Credit Default Swaps, 4 ENTREPRENEURIAL Bus. L.J. 407, 416 (2010) (arguing that disclosure of AIG's liabilities as a CDS protection seller might have alerted protection buyers, and possibly even regulators, to the AIG situation). Imposing such a disclosure requirement on protection sellers should not be costly. Cf. 12 C.F.R. $\$ 337.2$ (d) (2020) (providing already that "all . . s standby letters of credit must be adequately reflected on the bank's published financial statements"). Generally accepted accounting principles already require the disclosure of certain loss contingencies in financial statements, although usually in notes to the statement, including "[g]uarantees of indebtedness of others." FASB ACCOUNTING STANDARDS CODIFICATION $\S 460-10-50-2$ (last updated Aug. 14, 2020) (requiring disclosure even if "the possibility of loss may be remote").

192. See supra note 180 and accompanying text.

193. See supra notes 10,93 and accompanying text. Although immaterial to this Article's analysis, AIG's immediate default threat was, on a purely technical level, being unable to post the necessary mark-to-market collateral to secure its protection buyers, rather than being unable to pay its underlying CDS obligations to those protection buyers. See Henkel, supra note 10, at 9798. 
difficult to anticipate correlations in advance. ${ }^{194}$ Indeed, "hidden correlations are only observable when there is full appreciation of the underlying variables." 195

Similarly, to set a protection buyer limit, regulators would have to identify correlated CDS protection sellers. ${ }^{196}$ Those correlated entities normally should include all of a protection seller's affiliates ${ }^{197}$ and any other members of a protection seller's "common enterprise." 198 But because different criteria are relevant to setting protection seller limits versus setting protection buyer limits, regulators should not take the relatively simplistic approach - which U.S. bank regulators took in a different context ${ }^{199}$ - of setting the same limit for both.

The foregoing analysis has shown that limiting CDS credit exposure could provide substantial benefits by helping to control systemic externalities. Indeed, if AIG had been subject to a protection seller limit that restricted its aggregate credit exposure to MBS, it might not have faced defaulting on its CDS obligations. ${ }^{200}$

The benefits of limiting CDS credit exposure appear to exceed its costs, most of which would be imposed by the above-discussed practical challenges. The most difficult practical challenge would be identifying correlations, but even imperfectly identifying them should provide real benefit by reducing the likelihood of a systemically important firm's failure. If limiting CDS credit exposure still preserves the bulk of the CDS market, that market's pricing efficiencies should continue, and any other costs should be marginal. ${ }^{201}$ CDS contracts still would be

194. See supra note 95 and accompanying text.

195. Schwarcz, Regulating Complexity in Financial Markets, supra note 95, at 223. During the late 1970s and early 1980s, for example, "investors failed to recognize an underlying correlation between mobile-home loans and the price of oil. An oil boom in Oklahoma drew an influx of oil workers, creating the nation's fastest growing market for mobile-home loans." Id. at 223-24. Then, "[w]hen oil prices crashed, drilling in Oklahoma ceased, resulting in massive unemployment and causing widespread defaults on the mobile-home loans." Id. at 224.

196. See supra note 183 and accompanying text.

197. See, e.g., Franklin A. Gevurtz, Groups of Companies, 66 AM. J. COMPAR. L. 181, 181, 210 (2018) (discussing the correlated creditworthiness of affiliated companies).

198. Cf. Rojc, supra note 184, at 919, 921-24 (observing that loans made to a bank's customer are also attributed to those with whom the customer forms a "common enterprise," which includes the customer's affiliates).

199. See supra notes 189-91 and accompanying text (observing that U.S. regulators set the same limit for both bank standby-letter-of-credit exposure and bank-lending exposure).

200. See supra note 193 and accompanying text.

201. Systemically important firms still could engage in CDS transactions so long as their CDS exposure does not subject them to default. See supra notes 179-85 and accompanying text. 
available to hedge credit risk with relatively low transaction cost,${ }^{202}$ to provide standardization and liquidity to otherwise fragmented bond markets ${ }^{203}$ and to facilitate price discovery in equity markets. ${ }^{204}$ From a cost-benefit standpoint, therefore, limiting credit exposure appears to be a viable regulatory approach for controlling the externalities caused by systemically risky CDS contracts that guarantee insurable interests.

2. Correcting Cognitive Biases. Correcting the cognitive biases that motivate protection sellers' excessive risk-taking is another way to control the externalities caused by systemically risky CDS contracts. ${ }^{205}$ Although human nature is not easily changed, studies have shown that cognitive biases can be addressed and sometimes improved. ${ }^{206}$ Professors Christine Jolls and Cass Sunstein have argued, for example, that such biases can be regulated through an approach they call

202. See, e.g., Anupam Chander \& Randall Costa, International Law and the Economic Crisis: Clearing Credit Default Swaps, 10 CHI. J. INT'L L. 639, 646-47 (2010) (discussing the transaction-cost benefits for a reference entity of transacting in the CDS market rather than in the bond market itself); Douglas B. Levene, Credit Default Swaps and Insider Trading, 7 VA. L. \& BUS. REV. 231, 252-53 (2012) ("[A] credit default swap contract is an attractive alternative to selling a loan or a bond[:] . . keeping the credit on the bank's books has benefits for managing the bank's overall relationship with the client [and]... avoids any necessity to obtain the borrower's consent to the assignment of a loan.").

203. See Martin Oehmke \& Adam Zawadowski, The Anatomy of the CDS Market, 30 REV. FIN. STUD. 80, 103-04 (2017) ("Overall, our evidence supports the view of the CDS market as an alternative trading venue that [effectively facilitates financing] for firms with fragmented and contractually heterogeneous bonds, which are illiquid and costly to trade.").

204. See Viral V. Acharya \& Timothy C. Johnson, Insider Trading in Credit Derivatives, $84 \mathrm{~J}$. FIN. ECON. 110, 138 (2007) (providing "empirical evidence that there is an information flow from the credit default swap markets to equity markets"). Regulation might also inadvertently reduce another possible, though narrower, benefit - the ability of CDS pricing to help assess whether a failed leveraged buyout ("LBO") should be avoided as constructively fraudulent. Michael Simkovic \& Benjamin S. Kaminetzky, Leveraged Buyout Bankruptcies, the Problem of Hindsight Bias, and the Credit Default Swap Solution, 2011 COLUM. BUS. L. REV. 118, 122 (suggesting that bankruptcy courts could use CDS pricing to help determine "whether a corporate debtor who has filed for bankruptcy was solvent" after giving effect to the LBO).

205. Yet another approach to control the externalities caused by systemically risky CDS contracts would be to impose a public governance duty on systemically important counterparties to such contracts. See, e.g., supra note 173 (questioning whether managers of systemically important firms should have some form of a public governance duty).

206. See, e.g., David Z. Hambrick \& Alexander P. Burgoyne, The Difference Between Rationality and Intelligence, N.Y. TIMES (Sept. 16, 2016), https://nyti.ms/2cM5MDU [https:// perma.cc/J3XB-KFBN] (describing a pair of studies published by psychologist Carey Morewedge and colleagues that found that computer training led to decreases in decision-making bias). 
"debiasing through law." ${ }^{207}$ The goal is to give people more control over their processing of information. ${ }^{208}$ Regulators could do this by making an event more "available" to individuals, such as by exposing them to a concrete instance of the event's occurrence. ${ }^{209}$ Ironically, this approach uses one type of cognitive bias - availability heuristics ${ }^{210}-$ to correct other cognitive biases.

For example, smokers are more likely to believe that smoking will harm their health if they are exposed to specific, poignant, and concrete narratives rather than general information regarding health risks. ${ }^{211}$ One study showed that foreign cigarette package warnings that are more pictorially graphic than U.S. text-only warnings are more effective in discouraging smoking. ${ }^{212}$ To reduce credit-card abuse, scholars have similarly suggested giving consumers "vivid-perhaps even shocking-information about real cases [of that abuse] that have gone wrong." 213

These debiasing strategies can inform CDS regulation. ${ }^{214}$ For example, regulators might consider explicitly warning CDS protection sellers of optimism bias and abstraction bias. ${ }^{215}$ Even a simple reminder

207. Christine Jolls \& Cass R. Sunstein, Debiasing Through Law, 35 J. LEGAL STUD. 199, 200 (2006)

208. Roy F. BAUMEISTER \& BRAD J. Bushman, SOCIAL PSYCHOLOGy AND HUMAN NAture 155 (2d ed. 2011); see Cass R. Sunstein, People Prefer System 2 Nudges (Kind of), 66 DUKE L.J. 121, 131-32 (2016) (arguing that people are generally more receptive to requirements that allow them to exercise flexibility and agency than to more cut-and-dried rules such as requiring a display of graphics).

209. Jolls \& Sunstein, supra note 207, at 210.

210. Availability bias is the tendency to focus on a recent or especially vivid example. Anabtawi \& Schwarcz, Regulating Systemic Risk, supra note 88, at 1366-67. People with recently divorced friends, for example, tend to overestimate the divorce rate. $I d$. at $1367 \mathrm{n} .72$.

211. Jolls \& Sunstein, supra note 207, at 210.

212. See generally Hua-Hie Yong, Ron Borland, James F. Thrasher, Mary E. Thompson, Gera E. Nagelhout, Geoffrey T. Fong, David Hammond \& K. Michael Cummings, Mediational Pathways of the Impact of Cigarette Warning Labels on Quit Attempts, 33 HEALTH PSYCH. 1410 (2014) (comparing Canadian, Australian, United Kingdom, and U.S. cigarette-package warnings).

213. See, e.g., Oskari Juurikkala, The Behavioral Paradox: Why Investor Irrationality Calls for Lighter and Simpler Financial Regulation, 18 FORDHAM J. CORP. \& FIN. L. 33, 56 (2012).

214. Cf. Frank Partnoy, Five Years After Lehman's Collapse, Bankers Still Haven't Confronted Their Biases, HARV. BUS. REV. (Sep. 16, 2013), https://hbr.org/2013/09/five-yearsafter-lehmans-collapse-bankers-still-havent-confronted-their-biases [https://perma.cc/7NSB-779A] (arguing that because "modern financial markets tempt human beings into cognitive error," bankers should be taught the limits of human cognition).

215. See supra notes 87-92 and accompanying text (discussing those biases). In this Article's context, recall that optimism bias is the tendency for financial guarantors to believe they can quantify unquantifiable risks. Relatedly, abstraction bias is the tendency for financial guarantors 
that cognitive biases have caused sophisticated parties to be devastatingly wrong in the past can encourage more critical reflection and accurate risk assessments. ${ }^{216}$ Regulators might also consider requiring credit officers of CDS protection sellers to attend lectures that emphasize that warning and caution against optimism and abstraction bias. Supplementing warnings with lectures has been shown to reduce cognitive biases more effectively than merely providing warnings. ${ }^{217}$

Regulators also could try to reduce optimism and abstraction biases further by making the possibility of having to pay on the CDS more concrete. For example, they could consider requiring at least systemically important protection sellers to engage in the type of stress testing currently mandated for government-designated systemically important financial institutions ("SIFIs"). ${ }^{218}$ SIFIs must engage in periodic financial "stress test" scenarios ${ }^{219}$ to motivate them to consider the possibility of, and to better prepare for, future periods when

to view their risk-taking more abstractly, and thus underestimate their risk, because they do not actually transfer their property at the time they make a guarantee.

216. See Anabtawi \& Schwarcz, Regulating Systemic Risk, supra note 88, at 1389. Although some may argue that after the financial crisis, financial guarantors already should see the possibility of another failure as "available," the reality is that even the most sophisticated parties have relatively short memories when making investment decisions. See, e.g., Erik F. Gerding, The Next Epidemic: Bubbles and the Growth and Decay of Securities Regulation, 38 CONN. L. REV. 393, 418, 422 (2006) ("The availability bias means that, as time passes since the last financial crisis, regulators and policymakers discount the potential for new crises and the need for regulations to avert those crises."); $c f$. Larry Light, Bondholder Beware: Value Subject to Change Without Notice, BloOMBERG (Mar. 29, 1993, 12:00 AM), http:/www.bloomberg.com/bw/stories/199303-28/bondholder-beware-value-subject-to-change-without-notice [https://perma.cc/2HSV-K6X3] (observing that bondholders generally chose higher interest rates, thereby "go[ing] for the gold," over protective event-risk covenants within only a few years after an event that seriously harmed unprotected bondholders).

217. See Markku Kaustia \& Milla Perttula, Overconfidence and Debiasing in the Financial Industry, 4 REV. BEHAV. FIN. 46, 47, 57 (2012).

218. To the extent systemically important protection sellers already are designated by the federal government as SIFIs - which may well be the case for many - this proposed stress-testing requirement would supplement any already-mandated stress testing. For the criteria for which institutions receive a SIFI designation, see Daniel Liberto, Systemically Important Financial Institution (SIFI), INVESTOPEDIA (Nov. 21, 2019), https://www.investopedia.com/terms/s/ systemically-important-financial-institution-sifi.asp [https://perma.cc/NW79-5MEG]. For a list of current SIFIs, see Global Systemically Important Financial Institutions (G-SIFIs), FIN. STABILITY BD., https://www.fsb.org/work-of-the-fsb/policy-development/addressing-sifis/global-systemicallyimportant-financial-institutions-g-sifis [https://perma.cc/5YU8-CC38].

219. BASEl COMM. ON BANKING SUPERVISION, BASEl III: A GlobAl Regulatory FRAMEWORK FOR MORE RESILIENT BANKS AND BANKING SYSTEMS 46-47 (2011) [hereinafter BASEl COMM., A GlOBAl Regulatory FramewORK], http://www.bis.org/publ/bcbs189.pdf [https://perma.cc/96ZW-BSTJ]. For a discussion of SIFI designation, see supra notes 186, 218. 
previously adequate liquidity and capital resources might prove inadequate. ${ }^{220}$ Officials from the Federal Reserve maintain that these tests create a "strong, accountable, and proactive risk culture." $221 \mathrm{CDS}$ stress testing might posit, for example, that a protection seller is required to pay multiple CDS contracts simultaneously. This requirement would be consistent with a framing approach: by better understanding potential adverse outcomes, protection sellers should be able to assess risks more accurately. 222

From a cost-benefit standpoint, correcting cognitive biases should be inexpensive. As discussed, it likely would involve explicitly warning systemically important CDS protection sellers of optimism and abstraction bias and requiring their credit officers to attend lectures that emphasize that warning and caution against those biases. Additionally, it might subject those protection sellers to periodic stress tests that motivate them to consider the possibility of, and to better prepare for, having to make future payouts during financially difficult conditions. In contrast, correcting cognitive biases should provide important benefits, such as reducing optimism and abstraction bias and creating a "strong, accountable, and proactive risk culture." 223 Although correcting cognitive biases would not control the externalities caused by systemically risky CDS contracts as clearly as limiting credit exposure, it should provide an important regulatory supplement to that approach.

3. Setting Capital Requirements. Another avenue to control the externalities caused by systemically risky CDS contracts is to set special capital requirements on systemically important protection sellers. ${ }^{224}$

220. See Chris Brummer, Soft LaW And the Global Financial System: Rule MAKING IN THE 21ST CENTURY 217 (2012).

221. Charles L. Evans, President \& Chief Exec. Officer, Fed. Rsrv. Bank of Chi., The Call for Proactive Risk Culture 3 (June 3, 2015), https://www.chicagofed.org/ /media/publications/ speeches/2015/060315-chicago-banking-symposium-charles-evans-print-pdf.pdf [https://perma. cc/ TRY6-UQ2R] ("It is incumbent on financial institutions to serve as their own first line of defense. A strong risk culture enables institutions to proactively identify and manage not only broad risks, but also risks that are specific to their business.").

222. See Jolls \& Sunstein, supra note 207, at 216 ("A strategy of debiasing through substantive law in response to consumers' optimism bias is to require that firms identify the potential negative consequences associated with their product or a particular use of their product rather than the positive consequences associated with (for instance) an alternative usage.”).

223. See Evans, supra note 221.

224. If and when regulators gain experience with setting special capital requirements on systemically important protection sellers, they could consider whether also to set special capital requirements on systemically important protection buyers. 
The goal would be to make such protection sellers robust enough to resist failure. These capital requirements could resemble-or supplement, in the case of protection sellers already subject to capital requirements - the risk-based capital requirements imposed on banks and other SIFIs ${ }^{225}$ and the claims-reserve requirements imposed on insurance companies. ${ }^{226}$ Risk-based capital requirements are intended to protect firms both against unexpected losses ${ }^{227}$ and against becoming excessively leveraged ${ }^{228}$ by requiring them to hold minimum levels of capital, usually equity. ${ }^{229}$

Systemically important firms are already subject to risk-based capital requirements, ${ }^{230}$ and certain of those firms are subject to riskbased capital surcharges for derivatives exposure generally. ${ }^{231}$ Regulators should analyze whether those requirements are sufficient to address CDS protection-selling risk and, if not, whether additional risk-based capital requirements may be appropriate. As part of that analysis, regulators should attempt to balance the benefits and costs of imposing supplemental requirements, recognizing that the costs are uncertain. Some economists argue that risk-based capital requirements have little associated public cost; others argue to the contrary. ${ }^{232}$ The

225. See BASEl COMM., A GlobAl Regulatory FrAMEWORK, supra note 219, at 12-29.

226. A claims reserve, sometimes called a balance-sheet reserve, is an actuarially determined amount of money set aside by insurance companies to pay policyholders. See Daniel Liberto, Claims Reserve, INVESTOPEDIA (May 15, 2009), https://www.investopedia.com/terms/c/claimsreserve.asp [https://perma.cc/9TCL-WRM7].

227. Kern Alexander \& Steven L. Schwarcz, The Macroprudential Quandary: Unsystematic Efforts To Reform Financial Regulation, in RECONCEPTUALISING GLOBAL FINANCE AND ITS Regulation 127, 136 (Ross P. Buckley, Emilios Avgouleas \& Douglas W. Arner eds., 2016).

228. See Hervé Hannoun, Deputy Gen. Manager, Bank for Int'l Settlements, The Basel III Capital Framework: A Decisive Breakthrough 10 (Nov. 22, 2010), http://www.bis.org/speeches/ sp101125a.pdf [https://perma.cc/GQ2T-VHMQ] (proposing a leverage ratio, "a simple measure of capital that supplements the risk-based ratio and which constrains the build-up of leverage in the system").

229. In its most pristine form, capital consists of equity. See id. at 3-4 (explaining why the Basel III regulatory framework defines capital in terms of common equity).

230. See supra notes 186, 218-19, 225-26 and accompanying text (discussing SIFIs and other firms that are subject to risk-based capital requirements).

231. See generally, e.g., Wayne Passmore \& Alexander H. von Hafften, Are Basel's Capital Surcharges for Global Systemically Important Banks Too Small?, 15 INT’L J. CENT. BANKING 107 (2019) (discussing G-SIB risk-based capital surcharges).

232. Compare Anat Admati \& Martin Hellwig, The Bankers' New Clothes: WHAT'S WRONG WITH BANKING AND WHAT TO Do ABOUT IT 98 (2013) (arguing that higher capital requirements on banks would have no associated public costs), with Jean Dermine, Bank Regulations After the Global Financial Crisis: Good Intentions and Unintended Evil, 19 EUR. FIN. MGMT. 658, 662 (2013) (arguing that higher capital requirements "might lead to inefficiently higher interest rates on bank loans ... [and also] induce social costs as banks reduce their supply 
misapplication of capital requirements also could have substantial costs. ${ }^{233}$ Because of these uncertainties, this Article does not recommend setting additional risk-based capital requirements to control CDS protection-selling risk.

4. Reexamining the G20 Regulatory Scheme. Because replacing the G20 regulatory scheme - which purports to reflect a twenty-nation international regulatory consensus -is politically unrealistic at this stage, the foregoing regulatory approaches are intended to complement and enhance that scheme, imperfect as it may be. Consider, for example, central clearing, the principal focus of the G20 scheme. Central clearing applies to most derivatives and is intended to reduce counterparty risk by ensuring the performance of a derivatives contract, even if a counterparty fails. ${ }^{234}$ The foregoing regulatory approaches would enhance central clearing by more specifically targeting the riskiest derivatives - systemically risky CDS contracts.

Without arguing to replace the G20 scheme, this Article nonetheless critiques it. For example, the Article has observed that central clearing inadvertently could increase systemic risk by concentrating counterparty risk in the CCPs. ${ }^{235}$ Yet if central clearing ultimately proves to reduce systemic risk, as the G20 suggests, it certainly should be appropriate to clear and settle derivatives contracts centrally. But if this is true, then it may also be appropriate to centrally clear and settle other financial contracts involving systemically important counterparties. ${ }^{236}$ The rationales for this expanded use of central clearing are precisely those advocated in this Article-that

of loans or securitise assets"), and Emilios Avgouleas, Bank Leverage Ratios and Financial Stability: A Micro- and Macroprudential Perspective 16-17 (Levy Econ. Inst. Working Paper No. 849, 2015), http://www.levyinstitute.org/pubs/wp_849.pdf [https://perma.cc/L5XP-TVY5] (arguing that higher capital requirements can create "uncertainty [that] severely undermines rather than reinforces market discipline"). See also Eduardo Porter, Recession's True Cost Is Still Being Tallied, N.Y. TIMES (Jan. 21, 2014), https://nyti.ms/1f4j1Jv [https://perma.cc/ZGW3-LJFR] (discussing criticisms of capital requirements).

233. See Schwarcz, Too Big To Fool, supra note 119, at 779-80 (observing that capital requirements generally are imposed on a countercyclical basis, and the mistiming or misapplication of countercyclical regulation can be devastating).

234. See supra notes 134-38 and accompanying text; $c f$. FIN. STABILITY BD., INCENTIVES TO CENTRALly ClEAR, supra note 128, at 1 ("The central clearing of standardised OTC derivatives is a pillar of the G20 Leaders' commitments to reform OTC derivatives markets in response to the financial crisis.").

235. See supra notes $148-49$ and accompanying text.

236. See generally Schwarcz, Central Clearing of Financial Contracts, supra note 66 (arguing for that broader application of central clearing, if central clearing actually reduces systemic risk). 
derivatives contracts generally are not inherently riskier than other financial contracts ${ }^{237}$ and that having one or more systemically important counterparties can magnify counterparty risk for any financial contract, not just derivatives. ${ }^{238}$ However, the G20 has yet to adopt this expanded approach.

In addition to central clearing, the G20 regulatory scheme includes two other derivatives-reform proposals: first, imposing minimum margin requirements for non-centrally cleared derivatives transactions, ${ }^{239}$ and second, requiring data reporting about OTC derivatives transactions to government-mandated trade repositories. ${ }^{240}$ Again, by specifically targeting systemically risky CDS contracts, this Section's regulatory approaches would supplement and augment those proposals. Similarly, this Article critiques those proposals without arguing to replace them. For example, minimum margin requirements can create unpredictable liquidity-funding demands, which can cause counterparty defaults. ${ }^{241}$ Also, even absent a regulatory requirement, sophisticated derivatives counterparties normally contract to post margin at levels appropriate to protect their interests. ${ }^{242}$ To the extent the minimum margin requirements impose high costs while providing relatively few benefits, ${ }^{243}$ they may not be advisable.

In contrast, the G20's proposed data reporting requirements are intended to increase transparency, which can be important given the complexity of derivatives and the fact that OTC derivatives transactions are privately negotiated. ${ }^{244}$ Also, reporting requirements

237. See supra Part I.B.

238. See supra Part II.B.

239. See supra notes 150-64 and accompanying text.

240. See Over-The-Counter Derivatives, supra note 24 (listing the G20's 2009 derivatives reforms).

241. See supra notes $153-54$ and accompanying text.

242. See supra notes $155-56$ and accompanying text.

243. See supra notes 156-64 and accompanying text. This Article has not independently assessed a possible second benefit of imposing the minimum margin requirements, which is to reduce international regulatory arbitrage. See BASEL COMM. ET AL., MARGIN REQUIREMENTS, supra note 151, at 3-4 (discussing how imposing minimum margin requirements might reduce regulatory arbitrage and prevent financial institutions that operate in low-margin jurisdictions from gaining a competitive advantage).

244. See Over-The-Counter Derivatives, supra note 24 (listing the G20's 2009 derivatives reforms). 
generally have relatively low costs. ${ }^{245}$ The Article therefore favors those requirements. ${ }^{246}$

\section{Regulating "Naked" Systemically Risky CDS Contracts}

A naked systemically risky CDS is thought to constitute the riskiest type of CDS because it does not protect an insurable interest. ${ }^{247}$ The protection buyer simply may be speculating, for example, on the creditworthiness of a bond it does not own. ${ }^{248}$ Some estimate that naked CDS contracts have "become the more prevalent use of CDS in the market." 249

1. Addressing Moral Hazard. As discussed, two risks are associated with naked CDS contracts - moral hazard and a multiplier effect. $^{250}$ The moral-hazard risk appears to be exaggerated. The supposition is that naked CDS protection can motivate financial institutions to act imprudently by protecting them against the consequences of their actions. One industry observer, for example,

245. See, e.g., Alex Edmans, Mirko S. Heinle \& Chong Huang, The Real Costs of Financial Efficiency When Some Information Is Soft, 20 REV. FIN. 2151, 2155, 2168 (2016) (observing that the "actual act of disclosure" tends to be low cost or costless due to advances in electronic communication and the quantity of information produced for other purposes, but cautioning that "a high-disclosure policy can still be costly because of its effect on real investment").

246. At least one commentator questions, however, whether the $\mathrm{G} 20$ reporting requirements, as currently implemented, focus on reporting valuable data. See Sinead Walley, G20 Derivatives Regulation-Equivalence or Divergence?, ALt. Inv. MGMT. Ass'N (Apr. 23, 2018), https:// www.aima.org/journal/aima-journal-edition-114/article/g20-derivatives-regulation-equivalenceor-divergence.html [https://perma.cc/XH3W-W2RZ] (observing that only "minutiae" is "now being reported to trade repositories" under the G20 scheme). The extent to which the G20 reporting requirements should be improved, especially for reporting on OTC derivatives transactions made up of systemically risky CDS contracts, is beyond this Article's scope.

247. See supra notes 114-23 and accompanying text. Naked systemically risky CDS contracts also might be riskier than other systemically risky CDS instruments because protection sellers of naked CDS contracts lack a subrogation claim in an underlying asset that could help to reimburse them. For example, a guarantor that pays a holder of a defaulted bond becomes subrogated to the holder's rights in the bond. Subrogation, BLACK's LAW DICTIONARY (11th ed. 2019). Even a defaulted bond may have some value to the guarantor. In naked CDS contracts, however, the protection buyer lacks rights in any underlying asset; therefore, there are no rights in an underlying asset for which the protection seller can become subrogated. In some jurisdictions, this distinction may be irrelevant because the law is not always clear whether CDS protection sellers actually have a subrogation claim after making payment. See Janis Sarra, Financial Market Destabilization and the Role of Credit Default Swaps: An International Perspective on the SEC's Role Going Forward, 78 U. CIN. L. REV. 629, 638 (2009) ("For cash-settled CDSs, unlike insurance, no title to claim passes and the protection seller receives no right of subrogation.").

248. See supra notes $115-16$ and accompanying text.

249. Fletcher, supra note 4, at 1088.

250. See supra notes $117-23$ and accompanying text. 
argues that a bank would be motivated to make risky loans if it could purchase CDS contracts to reduce the risk of borrower default. ${ }^{251}$ That argument, however, lacks business sense. No bank would be able to purchase creditworthy protection, at a reasonable price, for guaranteeing risky loans. Furthermore, that example does not even appear to represent naked CDS contracts. ${ }^{252} \mathrm{~A}$ related supposition is that CDS protection can reduce a lender's incentives to monitor or accurately appraise risk. ${ }^{253}$ This similarly lacks business sense because no rational CDS counterparty would sell protection on loans without, itself, monitoring and appraising those loans. ${ }^{254}$

2. Addressing the Multiplier Effect. The greater risk of a naked systemically risky CDS is its multiplier effect. For example, naked CDS contracts can "allow speculators to write $\$ 10$ trillion in derivative contracts on a $\$ 1$ trillion market for mortgage bonds, just as a bookie can take in $\$ 100,000$ in bets on a horserace with a $\$ 10,000$ winner's purse." ${ }^{255}$ This enables a protection seller to leverage its CDS liabilities more highly compared to the amount of CDS protection it could sell on the underlying financial obligation alone. ${ }^{256}$ If a highly leveraged protection seller makes a bad bet, it may be unable to pay those liabilities and will default. ${ }^{257}$ If that defaulting protection seller is

251. See supra note 122 and accompanying text.

252. See supra note 122 (questioning whether that industry observer's example even represents a naked CDS, given that the bank presumably is buying CDS protection on a loan it still owns).

253. See supra note 121 and accompanying text.

254. The counterargument that the lender "is in the best position to" engage in that monitoring, see supra note 123 and accompanying text, is naive, ignoring the reality of the massive financial guarantee industry. Indeed, the above moral-hazard arguments parallel the argument attributing much of the financial crisis' excessive risk-taking to the so-called originate-todistribute model of securitization, in which originators of risky loans sell them to third parties. See, e.g., Amiyatosh Purnanandam, Originate-to-Distribute Model and the Subprime Mortgage Crisis 1 (FDIC Ctr. for Fin. Rsch., Working Paper No. 2010-08, 2010), https://www.fdic.gov/bank/ analytical/cfr/2010/wp2010/2010-08.pdf [https://perma.cc/7LU9-YN6N]. These sales are presumed to transfer risk on the loans away from the originators, thereby creating moral hazard that encourages originators to make even riskier loans. Id. That argument fails to explain, however, why those third parties - or why investors in and financial guarantors of securitization transactions sponsored by those third parties-accept that risk.

255. Stout, supra note 2, at 28.

256. Cf. id. ("[Naked CDS contracts] can magnify shocks in underlying markets and amplify them into risks that are many times larger than the underlying market itself.").

257. See John Geanakoplos, Leverage Caused the 2007-2009 Crisis, in SYSTEMIC RISK IN THE FinANCIAL SECTOR: TEN YeARS AFTER THE GlobAL FinANCIAL CRISIS 235, 248-51 (Douglas W. Arner, Emilios Avgouleas, Danny Busch \& Steven L. Schwarcz eds., 2019) (arguing that leverage was the primary cause of the financial crisis). 
systemically important, and thus its naked CDS is systemically risky, its default could threaten economic stability. ${ }^{258}$

The approaches recommended in Section B for regulating systemically risky CDS transactions - setting credit exposure limits and correcting cognitive biases ${ }^{259}$-also should apply to regulating naked systemically risky CDS instruments because neither of those approaches is conditioned on whether the protection buyer has an insurable interest. Moreover, setting a credit exposure limit on protection sellers-or in this Article's parlance, a protection seller limit-could directly control the multiplier effects of naked systemically risky CDS contracts and restrict a systemically important protection seller's correlated CDS liabilities to an aggregate amount it could feasibly pay. ${ }^{260}$ Thus, setting a protection seller limit would control the multiplier effect's systemic danger-even if the protection seller makes a bad bet, it should be able, assuming the protection seller limit is wisely chosen ${ }^{261}$ to pay its naked CDS liabilities.

With one exception, regulation setting credit exposure limits and correcting cognitive biases for naked systemically risky CDS contracts should have the same costs and benefits as regulation setting those limits and debiasing those biases for the other systemically risky CDS contracts discussed in Section B. The costs and benefits should be the same because neither of these regulatory approaches turns on whether the protection buyer has an insurable interest. From a cost-benefit standpoint, therefore, these regulatory approaches also should be appropriate for controlling the externalities caused by naked systemically risky CDS contracts. The exception makes this conclusion even stronger. Setting credit exposure limits-particularly protection seller limits-would provide even greater benefit for naked systemically risky CDS contracts by controlling the multiplier effect.

3. Considering a Ban. Another possible approach to regulating naked systemically risky CDS contracts would be simply to ban them. Regulators could do this, for example, by imposing an insurableinterest requirement on all systemically risky CDS contracts. Some

258. See supra note 166 and accompanying text (defining CDS contracts that have one or more systemically important counterparties as systemically risky CDS contracts).

259. Recall that this Article does not yet recommend a third possible approach - setting capital requirements. Supra notes 230-33 and accompanying text.

260. See supra notes $179-80$ and accompanying text.

261. See supra notes $187-95$ and accompanying text (analyzing how to set the limit). 
commentators advocate a ban, ${ }^{262}$ and the European Union ("EU") already has banned the issuance of naked CDS contracts on sovereign debt issued by the EU or its member states. ${ }^{263}$

This Article is agnostic on whether naked systemically risky CDS contracts should be banned. As discussed below, there is insufficient information to estimate the cost-benefit outcome of a ban. Even assuming that a ban on naked systemically risky CDS instruments would considerably further reduce systemic externalities beyond the reduction achieved by setting credit exposure limits and correcting cognitive biases, the costs of such a ban would include eliminating the pricing and other efficiencies of those contracts.

There is unresolved controversy, though, whether naked CDS contracts actually provide efficiencies and if so, to what extent. ${ }^{264}$ Some argue, for example, that the sole purpose of naked CDS contracts is speculation, which provides no efficiencies. ${ }^{265}$ A prominent derivatives scholar thus contends that because naked CDS contracts do not "provide price discovery benefits," they cannot "provide[] important external social benefits in the form of more liquid markets and more accurate or 'efficient' market prices." ${ }^{266}$ Although those types of benefits might result from "[e]xchange-based trading in which multiple buyers and sellers post their bid and ask prices produc[ing] price

262. See, e.g., Wolfgang Münchau, Time To Outlaw Naked Credit Default Swaps, FIN. TIMES (Feb. 28, 2010), https://on.ft.com/3gb7fjB [https://perma.cc/3S77-EGXH]; cf. Hazen, supra note 145, at 134-35 (suggesting that although the "justification" for imposing the insurable-interest requirement to insurance policies "is paternalism," which "is controversial since it sacrifices freedom of contract for what policy makers deem to be consistent with "the common good," "policy makers have wisely recognized that a paternalistic approach is appropriate when dealing with risk-shifting using insurance products [and the] justifications for substantive regulation of insurance contracts may be equally applicable to derivatives regulation").

263. Raphael M. Russo, Europe Restricts "Naked" Credit Default Swaps and Short Sales, HARV. L. SCH. F. ON CORP. GOVERNANCE (Dec. 27, 2011), https://corpgov.law.harvard.edu/2011/ 12/27/europe-restricts-naked-credit-default-swaps-and-short-sales [https://perma.cc/SDV2-J5AX].

264. Cf. supra notes 201-04 and accompanying text (discussing the pricing efficiencies of nonnaked CDS instruments).

265. See, e.g., Münchau, supra note 262 ("A naked CDS purchase means that you take out insurance on bonds without actually owning them. It is a purely speculative gamble. There is not one social or economic benefit."). Professor Hazen similarly suggests that CDS contracts should be regulated like insurance in order to reduce moral hazard. Hazen, supra note 145, at 130-31. That would have the practical effect of prohibiting naked CDS contracts. Mr. Charap observes, as a matter of positive law, that the Dodd-Frank Act prohibits CDS contracts from being regulated as insurance contracts under state insurance laws. Charap, supra note 118, at 156.

266. Stout, supra note 2, at 30-31 (making this argument for all OTC derivatives trading, which includes naked CDS contracts). 
quotations that can be made publicly available," 267 naked CDS speculation "involves private, bilateral agreements entered between parties with no obligation to report either the fact of their transaction, or their transaction terms, to the outside world." ${ }^{268}$

Others argue, in contrast, that selling naked CDS protection can make markets more robust. Sam Jones, a prominent industry observer, contends that even without price discovery, "there is a palpable social and economic benefit to naked CDS positions." ${ }^{269}$ Using the sovereign bond market as an example, Jones observes that in 2004, some hedge funds invested in buying naked CDS protection, for a relatively low fee, against the possibility of defaults on sovereign bonds-which the hedge funds did not own-of the Eurozone's financially weakest member states, including Greece. ${ }^{270}$ The hedge funds believed that the interest rates on Greek bonds were too low and that eventually investors would appreciate that nation's risk, causing the prices on those Greek bonds to fall. ${ }^{271}$ The hedge funds then purchased at those discounted prices Greek bonds that matched, as closely as feasible, the protection on their naked CDS contracts. ${ }^{272}$ This helped stabilize the price of Greek debt when few other investors were willing to purchase those bonds. ${ }^{273}$ The naked CDS, in other words, facilitated a form of arbitrage to help correct imperfect market pricing. For this and other reasons, several derivatives scholars agree that naked CDS contracts can provide pricing efficiencies, even without price discovery. ${ }^{274}$

This Article therefore recommends setting credit exposure limits and correcting cognitive biases to regulate naked systemically risky CDS contracts. Because the G20's regulatory scheme does not turn on

267. Id. at 31 .

268. Id.

269. Sam Jones, The Benefits of Naked CDS, Fin. Times (Mar. 2, 2010, 3:59 AM), https://ftalphaville.ft.com/2010/03/02/161556/the-benefits-of-naked-cds [https://perma.cc/6HUKRCXE].

270. Id.

271. Id. Greek bond prices would fall if investors eventually appreciate that the interest rates on those bonds would not fully compensate them. Those investors, therefore, would only offer a discounted price to purchase those bonds.

272. Jones, supra note 269.

273. Id. ("TT]he boon from hedge funds looking to hoover-up Greek debt is undeniable.").

274. See Feder, supra note 63, at 719 ("Theoretically, a market can have a perfect balance of natural long and short hedgers; realistically, however, speculators fill a counterparty void."); Lynch, Gambling by Another Name, supra note 120, at 118-19 ("There is little doubt that speculators add liquidity to the derivatives markets. Most importantly, without speculators, potential hedgers would have to find other hedgers with an exactly (or nearly exactly) opposite position .... . Finding such hedgers ... may be costly and often impossible."). 
whether a CDS contract guarantees an insurable interest, these regulatory recommendations should supplement the G20 regulatory scheme to the same extent discussed in Section B. ${ }^{275}$

\section{Regulating Failures}

Absent banning all systemically risky CDS contracts, which this Article does not advocate, ${ }^{276}$ even the best regulatory efforts cannot completely eliminate CDS risk. Limiting credit exposure, for example, is unlikely to prevent the occasional failure of systemically important counterparties. Nor is human nature well enough understood to completely avoid the influence of cognitive biases, such as optimism and abstraction biases.

Regulation therefore should not only try to prevent systemically important failures, as discussed in Sections B and $\mathrm{C}$ above, but should also try to mitigate the harm that inevitable failures can cause. This dual approach takes inspiration from chaos theory, which holds that in complex engineering systems-as well as in complex financial systems - failures are almost inevitable. ${ }^{277}$ Therefore, CDS regulation should also focus on limiting the harmful consequences of those failures. ${ }^{278}$ Although a comprehensive analysis of such limitations would be lengthier than this Article allows, a few observations may be in order.

U.S. law provides important regulatory precedents for limiting the harmful consequences of failures by requiring firms that are subject to consequential failures to mutualize their risk - that is, to share the

275. More specifically, this Article's recommendations for regulating naked systemically risky CDS contracts should supplement the G20 regulatory scheme to the same extent this Article has argued that its recommendations for regulating systemically risky CDS contracts guaranteeing an insurable interest should supplement it.

276. Cf. supra notes 262-74 and accompanying text (advocating against a ban of naked systemically risky CDS contracts and explaining why it is difficult to assess the merits of such a ban).

277. See Schwarcz, Regulating Complexity in Financial Markets, supra note 95, at 248-49. One aspect of chaos theory is deterministic chaos in dynamic systems, which recognizes that the more complex the system, the more likely it is that failures will occur. $I d$. at 248 . Thus, the most successful (complex) systems are those in which the consequences of failures are limited. Id. In engineering design, for example, such consequences are limited by decoupling systems through modularity that helps to reduce a chance that a failure in one part of the system will trigger a failure in another part. $I d$.

278. Cf. Iman Anabtawi \& Steven L. Schwarcz, Regulating Ex Post: How Law Can Address the Inevitability of Financial Failure, 92 TEX. L. REV. 75, 92, 102 (2013) (developing that argument for limiting the harmful consequences of inevitable systemic shocks). 
risk among multiple parties. ${ }^{279}$ In the banking industry, for example, the U.S. Federal Deposit Insurance Corporation ("FDIC") requires that deposit-taking banks mutualize their risk by paying into a fund that reimburses the FDIC for guaranteeing deposit accounts. ${ }^{280}$ The FDIC guarantee limits the harm to depositors caused by a bank's default and thus reduces the chances of harmful bank runs. ${ }^{281}$ To compensate for possible reactor accidents in the nuclear industry, the Price-Anderson Act likewise requires each owner of a nuclear reactor to share the risk by contributing collectively to a multi-billion-dollar self-insurance fund. ${ }^{282}$ In the traditional insurance industry, states typically require insurers share the risk by contributing collectively to a fund that ensures policyholders are paid even if an insurer fails. ${ }^{283} \mathrm{In}$ the derivatives industry itself, central clearing already represents a form of risk mutualization to limit counterparty risk. ${ }^{284}$

To further mutualize CDS risk, regulators could consider requiring systemically important CDS protection sellers to pay into a CDS-payment protection fund. The fund would be available to pay protection buyers in the event of a protection seller's default. Furthermore, requiring those CDS protection sellers to make up-front payments to the fund might even help to reduce their abstraction bias. $^{285}$

Some argue that requiring firms to pay into risk-mutualizing funds could create moral hazard by protecting them against their own risky action. ${ }^{286}$ There is, however, a strong argument to the contrary.

279. Schwarcz, Central Clearing of Financial Contracts, supra note 66, at 1365.

280. See 12 U.S.C. $\$ 1811$ (2018).

281. See, e.g., Steven A. Ramirez, The Law and Macroeconomics of the New Deal at 70, 62 MD. L. REV. 515, 543-44 (2003).

282. U.S. NUCLEAR REG. COMM'N, NUCLEAR INSURANCE AND DISASTER RELIEF 1 (2019), https://www.nrc.gov/docs/ML0327/ML032730606.pdf [https://perma.cc/2CKP-5PP3].

283. See, e.g., Martin F. Grace \& Hal S. Scott, An Optional Federal Charter for Insurance: Rationale and Design, in THE FUTURE OF INSURANCE REGULATION IN THE UNITED STATES 55, 90-91 (Martin F. Grace \& Robert W. Klein eds., 2009) (comparing state insurance funds with the FDIC deposit fund).

284. Schwarcz, Central Clearing of Financial Contracts, supra note 66, at 1331, 1365.

285. See supra text accompanying notes 89-90 (describing abstraction bias).

286. For example, the idea of a risk-mutualizing systemic risk fund was originally included in the bill that would become the Dodd-Frank Act. H.R. 4173, 111th Cong. § 210(n) (as introduced in House of Representatives, Dec. 2, 2009) (proposing a "Systemic Dissolution Fund" for winding down failed financial companies that pose a "systemic threat," with the fund to be maintained by "risk-based assessments" on large financial institutions). While the original bill did not set a limit on the size of the fund, id. $\S 210(\mathrm{n})(5)$, a parallel Senate bill would have set the target size of the fund at $\$ 50$ billion, S. 3217, 111th Cong. $\$ 210(n)(5)$ (as printed Apr. 29, 2010). Senator Richard 
The very requirement to pay into a risk-mutualizing fund, such as a CDS-payment protection fund maintained by protection sellers, should motivate those parties to monitor and help control each other's risktaking. Controlling that risk-taking would help avoid depleting the fund, thereby saving those parties from having to pay additional amounts to replenish the fund. ${ }^{287}$

Regulators also might consider limiting the harmful consequences of the failures of systemically important CDS counterparties by requiring those parties to "reinsure" their guarantee liabilities, as do traditional insurance companies. Reinsurance refers to insurers contractually transferring portions of their risk, especially in the case of major catastrophes, to other parties, known as reinsurers. Reinsurance enables an insurer to pay its policyholders. ${ }^{288}$ It also helps to prevent an insurer from failing by enabling it to recover all or part of the payments it makes to its insured policyholders. ${ }^{289}$ A complete analysis of reinsurance, which is highly specialized, is beyond this Article's scope. ${ }^{290}$

This Article therefore recommends targeted derivatives regulation, a model for which is in the Appendix, that would limit the credit exposure of systemically important CDS counterparties, try to correct the cognitive biases that motivate excessive risk-taking by those counterparties, and try to mitigate any harm to the public caused by

Shelby pushed through an amendment to the Senate bill, arguing that the $\$ 50$ billion "honey pot" would increase moral hazard by institutionalizing bailouts at the cost of "innocent taxpaying American families." See 156 CONG. REC. 7222 (2010) (statement of Sen. Richard Shelby) ("Wall Street gamblers . . . are happy to enjoy the upside but want to socialize the downside."); $i d$. at $7231,7308,7310$ (recording the passage of Senate Amendment 3827, which contained provisions striking the target value of the fund and the initial capitalization from risk-based assessments on large financial institutions). For a discussion of the moral-hazard debate over government deposit insurance of banks, see generally Thomas M. Hoenig, Vice Chairman, FDIC, Deposit Insurance: Addressing Its Moral Hazard Effect (Oct. 11, 2017), https://www.fdic.gov/news/news/speeches/ spoct1117.pdf [https://perma.cc/R4M4-FYSL].

287. Steven L. Schwarcz, Controlling Financial Chaos: The Power and Limits of Law, 2012 WIS. L. REV. 815, 831. CDS protection buyers could further protect themselves by requiring their protection sellers to put up collateral, which is marked to market. Shadab, supra note 191, at 436. This type of requirement, however, could be very expensive.

288. See Am. ACAd. of Actuaries Catastrophe Mgmt. Work Grp., Catastrophe EXPOSURE AND INSURANCE INDUSTRY CATASTROPHE MANAGEMENT PRACTICES 7-15 (2001), https://www.actuary.org/sites/default/files/pdf/casualty/catastrophe_061001.pdf [https://perma.cc/ QA5T-ETTL].

289. Id.

290. For an overview of reinsurance and its costs and benefits, see Daniel Schwarcz \& Steven L. Schwarcz, Regulating Systemic Risk in Insurance, 81 U. CHI. L. REV. 1569, 1613-18 (2014). 
inevitable CDS-market failures. These recommendations should complement the G20 regulatory scheme.

\section{CONCLUSION}

The perception that derivatives are exotic and uniquely risky financial instruments has given rise to a regulatory patchwork described as confusing, incomplete, and contradictory. This Article rethinks how derivatives should be regulated. ${ }^{291}$ In contrast to much existing scholarship, which analyzes derivatives under somewhat arcane industry-derived categories, the Article deconstructs derivatives by their economic functions into two categories of traditional legal instruments-option contracts and guarantees. Like these instruments, most derivatives are neither exotic nor uniquely risky.

The Article explains why the potential for derivatives to create very significant risk is primarily limited to CDS contracts, the category of derivatives that function as financial guarantees. The Article also explains why financial guarantee risk, and thus CDS risk, is magnified when the contract has one or more systemically important counterparties, which is typical of CDS contracts. Moreover, the absence of an insurable-interest requirement under some CDS contracts can even further magnify that risk. ${ }^{292}$

The Article then analyzes how CDS contracts that have one or more systemically important counterparties should be regulated and how the absence of an insurable interest should affect that regulation. Recognizing that even the best regulation cannot eliminate CDS risk, the Article also examines how to regulate the failures that inevitably will occur.

291. This Article analyzes how to regulate, not who should regulate, derivatives. For example, it does not analyze which regulatory bodies should set protection seller limits and protection buyer limits. See supra notes 187-91 and accompanying text. Others have examined, and continue to analyze, who should regulate derivatives. Compare BARR ET AL., supra note 120, at 1168-71, 1177-79 (discussing the jurisdictional "fight over OTC derivatives regulation" in the United States), and id. at 1179-80 (discussing the coordination of an international regulatory response), with Hazen, supra note 145, at 135 ("The overlapping nature of the sophisticated financial markets makes it difficult to identify the most natural regulator. It follows that instead, we should look for the most suitable regulator in terms of expertise and understanding of the complex financial and derivatives markets.").

292. See supra notes 118-19 and accompanying text (describing the insurable-interest requirement and how it helps reduce moral hazard). 
Finally, the Appendix proposes the text of a model law to implement the Article's regulatory recommendations. The model law is intended to complement and enhance the existing G20 regulatory scheme for derivatives, which is followed by the United States and many other countries. ${ }^{293}$ This follows the well-respected approach of building normative legal improvements onto an established positive law foundation.

Calls for derivatives regulation are understandable; underregulation doubtless contributed to the 2007-2008 financial crisis, and regulatory solutions could doubtless help prevent future crises. But regulators must understand and differentiate the types of derivatives and their potential risk in order to craft meaningful solutions. Such solutions should address derivatives risk that threatens economic stability, without impairing the risk-shifting benefits of the derivatives market as a whole.

293. The G20's principal regulatory goal, for example, is to require central clearing of most derivatives contracts; this is intended to reduce counterparty, and thus systemic, risk by ensuring the performance of a derivatives contract even if a counterparty fails. See supra notes 125-37 and accompanying text. This Article's three regulatory approaches would supplement, and thereby augment, central clearing by specifically targeting the riskiest derivatives - systemically risky CDS contracts. Except as observed, this Article does not independently assess the merits of central clearing. The Article has noted, however, that central clearing inadvertently could increase systemic risk by concentrating counterparty risk. See supra note 234 and accompanying text. If central clearing actually reduces systemic risk, it should be appropriate not only, as the G20 suggests, for derivatives but also for all large financial contracts with systemically important counterparties. See supra notes 235-38 and accompanying text. 


\section{APPENDIX: MODEL REGULATORY LANGUAGE IMPLEMENTING THIS ARTICLE'S RECOMMENDATIONS ${ }^{294}$}

\section{Preamble}

This Law applies to credit-default swap ("CDS") contracts that have one or more systemically important counterparties. These contracts can cause significant public harm if a systemically important protection seller's default leads to its failure or if protection-seller defaults cause a systemically important protection buyer's failure. To control that harm, this Law limits the credit exposure of systemically important counterparties on CDS contracts and establishes procedures to help correct the cognitive biases that motivate excessive risk-taking by those counterparties.

\section{Chapter I: Scope, Interpretation, and Definitions}

\section{Article 1: Scope and Interpretation}

(1) This Law applies to all CDS contracts, whether or not they guarantee insurable interests. It shall supplement, and not restrict, the application of other laws and regulations that apply to CDS contracts.

(2) The CDS Regulator may issue such rules and regulations as may be necessary to administer and interpret this Law.

(3) This Law shall be liberally construed to promote its remedial purposes described in the Preamble.

\section{Article 2: Definitions}

In this Law, the following terms shall have the following meanings:

(1) "CDS" and "CDS contract" each means a credit-default swap, which includes any contractual or other arrangement in which a protection seller agrees, in exchange for the payment of a fee or other consideration by or on behalf of a protection buyer, to assume or otherwise guarantee credit risk with respect to debt obligations.

294. [The bracketed footnotes to this Law are solely informational.] 
(2) "CDS Regulator" means [name(s) of government agency or other body with primary regulatory authority under this Law ${ }^{295}$.

(3) "CDS Risk Officer" shall have the meaning set forth in Ch. IV, Art. 1(1) of this Law.

(4) "Cognitive bias" means an implicit simplification of a person's perception of reality, and includes optimism bias (in this context, the tendency of protection sellers to believe they can quantify unquantifiable risks) and abstraction bias (in this context, the tendency of protection sellers to underestimate risk because they do not actually transfer funds at the time they enter into a CDS contract).

(5) "Common enterprise" means the relationship existing between two or more protection sellers when-

(a) such protection sellers are related directly or indirectly through common control; or

(b) the CDS Regulator determines, based upon an evaluation of facts and circumstances (including substantial financial interdependence or an "affiliate" relationship under applicable accounting standards ${ }^{296}$ ), that a common enterprise exists between such protection sellers. ${ }^{297}$

(6) "Correlated" means that an event triggering a protection seller's payment obligations under a CDS contract is or may be related to one or more events triggering that protection seller's payment obligations under other CDS contracts, as determined by the CDS Regulator.

(7) "Counterparty" means a party to a CDS contract, whether as protection seller or protection buyer.

295. [In the United States, this could be the CFTC and SEC. See Derivatives, SEC (May 4, 2015), https://www.sec.gov/spotlight/dodd-frank/derivatives.shtml [https://perma.cc/M7GU-VTUB] (describing distribution of swap agreement oversight between the CFTC and SEC). It might also include appropriate Federal banking agencies, such as the Office of the Comptroller of the Currency, the FDIC, or Board of Governors of the Federal Reserve System.]

296. [Cf. 12 C.F.R. pt. 252 (2020) (discussing the inclusion of affiliates as counterparties for single-counterparty credit-limit purposes).]

297. [Cf. id. § 32.5(c) (defining "common enterprise" for the purpose of bank lending limits).] 
(8) "Insurable interest" means an interest of the protection buyer to receive payments under debt obligations guaranteed by a CDS contract.

(9) "Notional amount" means the principal and accrued interest on debt obligations guaranteed by CDS contracts. ${ }^{298}$

(10) "Protection buyer" means the party to a CDS contract for which the protection seller agrees to assume or otherwise guarantee credit risk with respect to debt obligations.

(11) "Protection buyer limit" means the lowest aggregate amount of CDS protection that, if unpaid when due, would impair the ability of a protection buyer to continue operating.

(12) "Protection seller" means the party to a CDS contract that agrees to assume or otherwise guarantee credit risk with respect to debt obligations.

(13) "Protection seller limit" means the lowest aggregate amount of CDS protection that, if required to be paid simultaneously, would impair the ability of a protection seller to continue operating.

(14) "Stress testing program" means the CDS-specific stress testing program implemented by Ch. IV, Art. 2 of this Law.

(15) "Systemically important" means any firm or other entity identified as systemically important by [name of relevant government agency or other body ${ }^{299}$.

(16) "Violation" shall include noncompliance.

\section{Chapter II: Protection Seller Limit}

Article 1: Scope

(1) This Chapter applies to any systemically important protection seller.

298. [See supra notes 96, 178 (observing that because CDS contracts guarantee debt obligations, their notional amount is the principal and accrued interest outstanding on those obligations).]

299. [In the United States, this would be the Financial Stability Oversight Council ("FSOC"). See Designations, U.S. DEP'T TREASURY, https://home.treasury.gov/policy-issues/financialmarkets-financial-institutions-and-fiscal-service/fsoc/designations [https://perma.cc/44NW-CTA6].] 
(2) The protection seller limit in this Chapter applies independently of any applicable lending limit. ${ }^{300}$

\section{Article 2: Limit on CDS Exposure as Protection Seller}

(1) A systemically important protection seller shall not permit the notional amount of any correlated exposure outstanding under CDS contracts to exceed its protection seller limit.

(2) If for reasons beyond its control, the notional amount of a protection seller's correlated exposure outstanding exceeds its protection seller limit under clause (1), such protection seller shall use its best efforts to reduce that exposure into conformity with its protection seller limit within 90 calendar days.

\section{Article 3: Determination of Protection Seller Limit}

(1) The protection seller limit shall be determined by the CDS Regulator, in consultation with the protection seller, as of the last business day of each preceding calendar year or, if so requested by the CDS Regulator, more frequently.

(2) Such determination shall take into account all relevant facts and circumstances, including the results of the stress testing program.

\section{Chapter III: Protection Buyer Limit}

Article 1: Scope

(1) This Chapter applies to any systemically important protection buyer.

(2) The protection buyer limit in this Chapter applies independently of any applicable lending limit. ${ }^{301}$

300. [In the United States, these lending limits are imposed under 12 U.S.C. $\$ 84$ (2018), which limits a bank's extensions of credit to any one person to 15 percent of the bank's capital and surplus (with additional 10 percent lending availability for loans fully secured by readily marketable collateral). Section 84 lending limits include derivatives exposure. Id. $\S 84(\mathrm{~b}) ; 12$ C.F.R. pt. 32. The Dodd-Frank Act and subsequent regulation imposed single-counterparty credit limits for the largest bank holding companies and foreign banking organizations. Dodd-Frank Wall Street Reform and Consumer Protection Act, Pub. L. No. 111-203, 124 Stat. 1376, 13762223, 1427 (2010) (codified at 12 U.S.C. $\$ 5365(\mathrm{e})$ ); 12 C.F.R. pt. 252).]

301. [These lending limits in the United States are discussed supra note 300.] 
Article 2: Limit on CDS Exposure as Protection Buyer

(1) A systemically important protection buyer shall not permit the total outstanding notional amount of CDS protection bought from any protection seller or from protection sellers representing a common enterprise to exceed its protection buyer limit.

(2) If for reasons beyond its control (including an unforeseeable merger or acquisition of protection sellers that creates, or increases the CDS exposure of, a common enterprise), the total outstanding notional amount of a protection buyer's CDS protection exceeds its protection buyer limit under clause (1), such protection buyer shall use its best efforts to reduce that total protection into conformity with its protection buyer limit within 90 calendar days.

\section{Article 3: Determination of Protection Buyer Limit}

(1) The protection buyer limit shall be determined by the CDS Regulator, in consultation with the protection buyer, as of the last business day of each preceding calendar year or, if so requested by the CDS Regulator, more frequently.

(2) Such determination shall take into account all relevant facts and circumstances, including consideration of any collateral securing the obligations of protection sellers to pay the protection buyer.

\section{Chapter IV: Debiasing and Stress Testing}

\section{Article 1: CDS Risk Officer and Education Program}

(1) Each systemically important protection seller shall designate a senior compliance officer as its CDS Risk Officer.

(2) The CDS Risk Officer shall be responsible for designing and implementing an education program of mandatory quarterly lectures and readings on the risks and cognitive biases attendant to CDS transactions, and shall provide the syllabus of such education program annually to the CDS Regulator. Such education program shall include, without limitation, narrative information on the 2007-2008 global financial crisis, American International Group's near-failure due to CDS exposure, the impact of these events on the careers of managers involved with CDS contracts, and the limits of financial modeling. 
(3) The CDS Risk Officer shall certify annually to the CDS Regulator that all of the protection seller's credit officers, traders, and other similar employees and contractors who are responsible for transactions involving CDS contracts have successfully satisfied the requirements of that education program.

(4) The CDS Risk Officer shall be responsible for approving all CDS protection sold by the protection seller. Such approval process shall take into account reasonably worst-case scenarios and potential risks.

\section{Article 2: Stress Testing Program}

(1) Each systemically important protection seller shall annually conduct a stress testing program for its CDS contracts. ${ }^{302}$

(2) For each correlated exposure, the stress testing program shall assume that the protection seller must simultaneously pay all of its CDS obligations triggered by that exposure.

(3) For each correlated exposure, the stress testing program also shall assume that the protection seller must simultaneously post all collateral required to meet margin requirements triggered by that exposure.

(4) The stress testing program will model any remaining CDS exposure under economic conditions at least as difficult as those that occurred during the Great Depression and the global financial crisis.

(5) The CDS Risk Officer shall distribute the results of the stress testing program to all of the protection seller's credit officers, traders, and other similar employees and contractors who are responsible for transactions involving CDS contracts. In such distribution, the CDS Risk Officer shall highlight the potential for CDS and other financial guarantee transactions to result in actual property transfers, including the posting of collateral.

302. [Cf. 12 U.S.C. $§ 5365(i)$ (requiring annual stress tests for nonbank financial companies supervised by the Board of Governors of the Federal Reserve System and banks with $\$ 250$ billion or more in assets); 12 C.F.R. $\$ 252.45$ (allowing the Board of Governors of the Federal Reserve System to require additional submissions for stress tests); BASEL COMM., A GLOBAL REGULATORY FRAMEWORK, supra note 219, at 46-47 (describing stress test requirements).] 
(6) The CDS Risk Officer also shall certify the results of the stress testing program in a report submitted annually to the CDS Regulator ${ }^{303}$ which shall publish that report on its website.

\section{Chapter V: Penalties for Violation}

\section{Article 1: Violation by Protection Seller}

(1) If a protection seller violates any provision of this Law, it shall pay to the CDS Regulator a penalty, for each day such violation remains uncured, equal to [_]\% of the notional amount of its then-outstanding total exposure under CDS contracts. ${ }^{304}$

(2) If a protection seller continues to violate a provision of this Law for more than 120 days, the CDS Regulator may suspend that protection seller's right to sell protection until the violation is cured and also may require that protection seller to disclose risks, economic information, and incentives for each CDS transaction to all relevant counterparties. ${ }^{305}$

(3) The failure of a protection seller to reduce its correlated exposure into conformity with the protection seller limit within 90 calendar days, as required by Ch. II, Art. 2(2), shall not constitute a violation of this Law so long as such protection seller is continuing to use its best efforts to bring its correlated exposure into such conformity.

\section{Article 2: Violation by Protection Buyer}

(1) If a protection buyer violates any provision of this Law, it shall pay to the CDS Regulator a penalty, for each day such violation remains uncured, equal to [_]\% of the notional amount of its then-outstanding total CDS protection bought. ${ }^{306}$

(2) If a protection buyer continues to violate a provision of this Law for more than 120 days, the CDS Regulator may suspend that

303. [Cf. 7 U.S.C. $\S 6 s(\mathrm{k})(3)$ (2018) (requiring the chief compliance officer of a swap dealer or major swap participant to submit an annual report on compliance procedures to the CFTC).]

304. [The relevant percentage should be material enough to constitute a meaningful penalty but still small enough not to jeopardize the protection seller's financial condition.]

305. [Cf. 17 C.F.R. $§ 23.431$ (2020) (requiring disclosure of a swap's risks and contractual qualities, as well as the swap dealer's incentives, when a swap dealer trades uncleared swaps with a counterparty other than another registered swap dealer or major swap participant).]

306. [The relevant percentage should be material enough to constitute a meaningful penalty but still small enough not to jeopardize the protection buyer's financial condition.] 
protection buyer's right to buy protection until the violation is cured.

(3) The failure of a protection buyer to bring its total protection into conformity with the protection buyer limit within 90 calendar days, as required by Ch. III, Art. 2(2), shall not constitute a violation of this Law so long as such protection buyer is continuing to use its best efforts to bring its total protection into such conformity.

Article 3: Violation by CDS Risk Officer

(1) If the CDS Regulator determines that a CDS Risk Officer is violating any provision of this Law, it may require the relevant protection seller to designate a different CDS Risk Officer.

(2) The CDS Regulator may impose a civil penalty of [\$ ] per day per violation on any CDS Risk Officer that the CDS Regulator determines is violating any provision of this Law. ${ }^{307}$

(3) The failure of a protection seller to monitor and require its CDS Risk Officer to comply with this Law shall itself constitute a violation by such protection seller for purposes of Art. 1 of this Chapter.

307. [The relevant amount should be material enough to constitute a meaningful penalty but still small enough not to deter capable managers from wishing to serve as CDS Risk Officers.] 